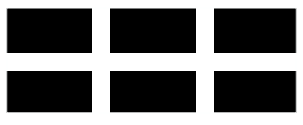

ThE William DAVIDSON INSTITUTE AT THE UNIVERSITY OF MICHIGAN BUSINESS SCHOOL

\title{
Interest Groups, Veto Points and Electricity Infrastructure Deployment
}

\author{
By: Witold J. Henisz and Bennet A. Zelner
}

William Davidson Institute Working Paper Number 711

July 2004 


\section{INTEREST GROUPS, VETO POINTS \\ AND ELECTRICITY INFRASTRUCTURE DEPLOYMENT}

Witold J. Henisz

and

Bennet A. Zelner

WORD COUNT: 11,901

In this paper we examine the effects of interest group pressure and the structure of political institutions on infrastructure deployment by state-owned electric utilities in a panel of 78 countries during the period 1970 - 1994. We consider two factors that jointly influence the rate of infrastructure deployment: (1) the extent to which the consumer base consists of industrial consumers, which are capable of exerting discipline on political actors whose competing incentives are to construct economically inefficient "white elephants" to satisfy the demands of concentrated geographic interests, labor unions and construction firms; and (2) veto points in formal policymaking structures that constrain political actors, thereby reducing these actors' sensitivity to interest group demands. A higher fraction of industrial customers provides political actors with stronger incentives for discipline, reducing the deployment of white elephants and thus the infrastructure growth rate, ceteris paribus. Veto points reduce political actors' sensitivity to interest group demands in general and thus moderate the relationship between industrial interest group pressure and the rate of infrastructure deployment.

Keywords: Electricity, Institutional Environment, Investment, Regulation, interest group, state owned enterprise

JEL Classifications: L94, L32, F21 


\title{
CONTACT INFORMATION
}

\author{
Witold J. Henisz \\ Assistant Professor of Management \\ The Wharton School \\ University of Pennsylvania \\ 2021 Steinberg Hall - Dietrich Hall \\ Philadelphia, PA 19104-6370 \\ henisz@wharton.upenn.edu \\ and \\ Bennet A. Zelner \\ Assistant Professor \\ G-04 Old North \\ McDonough School of Business \\ Georgetown University \\ Washington, DC 20057 \\ zelnerb@georgetown.edu
}

\section{Acknowledgements}

Both authors contributed equally and list their names alphabetically on joint work. Both authors acknowledge funding for this research from the University of California Energy Institute. Zelner acknowledges additional funding from the Lynde and Harry Bradley Foundation and the Edgar F. Kaiser Chair at the Haas School of Business, University of California, Berkeley. Henisz acknowledges additional funding from the Reginald H. Jones Center for Management Policy, Strategy, and Organization at The Wharton School, University of Pennsylvania. Thanks to Severin Borenstein, Rachel Croson, Jose de la Torre, Alexander Dyck, Tom Gilligan, Florencio Lopez-de-Silanes, Edward Mansfield, Mathew McCubbins, Will Mitchell, David Mowery, Jeffrey Nugent, Dennis Quinn, George Tsebelis, Joel Waldfogel, Oliver Williamson and Jan Zabojnik for their comments on previous drafts. Any errors are the responsibility of the authors. 


\section{Introduction}

In this paper we investigate empirically the joint effects of interest group pressure and the veto points in a country's formal political institutions on state-owned electric utilities' infrastructure deployment rates. It is widely accepted that state-owned enterprises (SOEs) invest inefficiently relative to their private sector counterparts. ${ }^{1}$ A central reason for this inefficiency is the efforts of political actors, unconstrained by the market forces associated with ownership and control of private sector firms, to use SOEs as a vehicle for redistributing wealth to salient political constituencies such as concentrated geographic interests, labor unions and construction firms. ${ }^{2}$ Specifically, political actors may direct SOEs to undertake "white elephant" investment projects that provide targeted economic benefits to these constituencies, even when the aggregate economic benefits of such projects such as increased output or service quality do not cover the economic (opportunity) costs borne by the broader polity. ${ }^{3}$

We examine how two elements of the political setting influence the extent to which political actors use SOEs to deliver targeted benefits: the political influence of industrial consumers of electricity, who bear the costs of white elephants without enjoying commensurate gains and can overcome collective action problems more easily than non-industrial consumers can; and the extent to which veto points in a nation's formal political institutions raise the costs of policymaking, thereby moderating political actors' sensitivity to interest group demands. Our analysis thus joins demand-side theories of policymaking - those focusing on interest group pressures—with supply-side theories—-those emphasizing formal decision rules and structures. ${ }^{4}$

The worldwide electricity sector prior to the early 1990s provides an appealing context in which to test our hypotheses. Infrastructure investment is inherently political as a result of the

\footnotetext{
${ }^{1}$ See, for example, Dyck (2001), Megginson and Netter (2001) and Vining and Boardman (1989).

${ }^{2}$ See, for example, Bertero and Rondi (2000), Chamberlin and Jackson (1987), Garrett and Lange (1995), Karp and Perloff (1995), Shleifer and Vishny (1994), and Willig (1994).

${ }^{3}$ See, for example, Boycko, Shleifer and Vishny (1996), Peltzman (1989) and Sheshinski and Lopez-Calva (1998).

${ }^{4}$ See Rodrik (1994) for a discussion of the need for a similar synthesis in the trade policy literature and Lohmann and O'Halloran (Lohmann and O'Halloran, 1994), Mansfield and Busch (1995) and Nollen and Quinn (1994) for empirical applications in this arena. See also Lohmann (1998) and Franzese (1999a) for applications in the realm of monetary policy.
} 
large quasi-rents associated with generation assets, the widespread consumption of output, and the common belief that large scale economies create the potential for monopoly abuse by providers. ${ }^{5}$ Moreover, in the electricity sector, state ownership and operation was the norm in virtually every country prior to 1990, and it is well documented that political actors used SOEs to pursue redistributive objectives through white elephants and other means. ${ }^{6}$ These policies became so costly that they eventually led to severe financial crises at various state-owned electric utilities around the globe, particularly in developing countries. ${ }^{7}$

We examine the infrastructure deployment patterns of state-owned electric utilities using a panel data set covering 78 countries during the period 1970 - 1994. Specifically, we assess the extent to which interest group pressures generated (and organized) by the industrial consumers of electricity combine with the level of veto points in the structure of a nation's formal political institutions to influence the annual rate of deployment of electricity generating capacity, ceteris paribus.

The results of our analysis are robust and strongly support our hypotheses. We find that an increase in industrial representation among the consumers of electricity reduces the rate of infrastructure deployment, ceteris paribus. As the level of veto points rises, the negative marginal effect of industrial representation declines in absolute magnitude because political actors are less sensitive to interest group demands. However, when industrial representation is negligible and political actors thus predisposed to cater to the demands of the pro-white elephant lobby, an increase in the level of veto points lowers the deployment rate by reducing political actors' sensitivity to this lobby.

\footnotetext{
${ }^{5}$ See, for example, Levy and Spiller (1994), Sidak and Spulber (1997), Spiller (1993) and Williamson (1976).

${ }^{6}$ See, for example, Levy and Spiller (1996), Savedoff and Spiller (1999), Soto (1999), and the World Bank (1995).

${ }^{7}$ See, for example, Bortolotti, Fantini and Siniscalco (2000).
} 


\section{Conceptual Development}

The arguments that form the basis of our hypotheses derive from three main bodies of literature, those on: (1) the inefficiency of state-owned enterprises, (2) interest group politics and (3) veto points.

\section{A. Inefficiency of State-owned Enterprises}

The literature on the inefficiency of state-owned enterprises begins with the assumption that political actors choose policies to maximize their political support. "White elephants"large-scale investment projects such as roads, ports, universities and power plants that directly benefit politically salient constituencies-are a particularly attractive vehicle for this purpose. These projects provide highly visible benefits stemming from increased employment ${ }^{8}$ to constituencies in the immediate regions in which they are built, as well as to national constituencies such as labor unions and the construction industry. ${ }^{9}$ Political actors may induce state-owned enterprises to undertake white elephant projects through their control of the budgetary process and appointment of key personnel. ${ }^{10}$ Because the criteria for building white elephants are largely political, however, many lack a strong efficiency rationale, and their concentrated political benefits come at a broader economic cost.

The Electricity Sector. In the electricity sector, many SOEs constructed plants whose investment or operating costs were too high to justify the economic benefits of the capacity that they added to the system. Such plants were built in uneconomic locations, such as a remote area far the sources of demand; relied on inappropriate technologies, such as a large coal-burning plant built where a smaller gas-fired plant would have been more economic; or were "goldplated" through the use of lavish materials and architectural designs.

Although the precise costs of white elephants are difficult to measure, the limited evidence is suggestive. In the Argentine electricity generation sector, for example, unit investment costs fell from US $\$ 7,200$ per kilowatt prior to privatization to US $\$ 1,930$

\footnotetext{
${ }^{8}$ In addition to providing direct benefits to those employed, regional employment produces a concentrated economic multiplier effect in the form of increased spending on locally available goods and services.

${ }^{9}$ See, for example, Cadot, Roller and Stephan (1999).

${ }^{10}$ See, for example, Baron (1991), Hird (1991) and Shepsle (1981).
} 
afterwards. ${ }^{11}$ In Thailand and Argentina, the cumulative burden of state-owned electricity investment accounted for over one half of total foreign-denominated debt by 1990. These countries are not exceptions but rather constitute the most extreme cases in a broader pattern. ${ }^{12}$

The greatest economic costs of white elephant policies, however, are those stemming from new plants whose output is superfluous or could have been more cheaply generated by improving the yield of existing capacity. For example, in 1989, Argentina had a capacity overhang of 45 percent, with over one-third of capacity typically under repair. ${ }^{13}$ In Hungary, thermal efficiency - the ratio of electric energy generated to the energy content of fuel consumed-averaged 31 percent during the $1980 \mathrm{~s},{ }^{14}$ as compared to 35 - 38 percent for a wellfunctioning gas turbine plant; in the Czech Republic, thermal efficiency was less than 25 percent at many plants. ${ }^{15}$ Available data on line losses, which reflect the fraction of electricity lost in transmission and are thus often used as a proxy for the quality and technical efficiency of a system, ranged as high as 30 percent in some cases and averaged around 14 percent among nonOECD countries in Latin America and Asia during the 1980s, as compared to 6.9 percent in the more developed countries of the EU.

More rigorous, corroborative evidence comes from studies demonstrating that the changes in management incentives that accompany privatization increase the efficiency of capital utilization. Several empirical studies compare the performance of SOEs with that of a matched set of private sector counterparts or with their post-privatization successors. ${ }^{16}$ La Porta and Lopez-de-Silanes compare output/labor and output/capital ratios for 218 Mexican firms before and after privatization, and conclude that privatization is associated with a 54.3 percent increase in output despite a decline in capital spending. ${ }^{17}$ Bertero and Rondi, taking a novel empirical approach, demonstrate the increased effect of financial leverage variables on

${ }^{11}$ See Artana, Navajas and Urbiztondo (2001).

${ }^{12}$ See, for example, Bortolotti et. al. (2001), Bortolotti, Fantini and Siniscalco (2000), Bourbakri and Cosset (1997), Dewenter and Malatesta (1998), D'Souza and Megginson (1999b) D'Souza and Megginson (1999a) and Megginson, Nash and Van Randenborgh (1994).

${ }^{13}$ See Vecchia (1993).

${ }^{14}$ See Magyar Villamos Muvek (2000).

${ }^{15}$ See Newbery (1998).

${ }^{16}$ See the reviews provided by Vining and Boardman (1989) and Megginson and Netter (2001).

${ }^{17}$ La Porta and Lopez-de-Silanes (1999). 
productive efficiency for Italian state-owned enterprises following the introduction of a new, more stringent corporate governance regime in $1987 .{ }^{18}$ Bortolotti et. al. find a 19 percent average increase in lines per employee after the privatization of 31 state-owned telecommunications companies. ${ }^{19}$

Current Analysis. The current analysis adds to this body of evidence by examining the effects of differences in political—as opposed to market—incentives on SOEs' deployment of white elephants. Following the existing literature on SOEs, we assume that political actors seek to maximize their support by providing policy benefits to constituents and effectively direct SOEs' behavior through the appointment process and budgetary control. We do not observe political actors' incentives or control mechanisms directly, but rather consider the effects of observable sources of political incentives-interest group pressure for more efficient SOE behavior - and constraints - the level of veto points in a nation's formal political institutionson state-owned electric utilities' generating capacity deployment rates.

\section{B. Interest Group Politics}

A substantial body of literature in political science ${ }^{20}$ and economics, ${ }^{21}$ which we collectively refer to as the "interest group politics literature," emphasizes how distributional conflicts among interest groups affect policy outcomes. Consistent with the literature on stateowned enterprises, this perspective views political actors as maximizing political support. However, rather than implicitly portray a specific set of interest groups-such as the beneficiaries of white elephants_as uniformly dominating political actors' incentives, the interest group politics literature takes an explicitly symmetric view of interest groups' role in the political process, emphasizing the relative strength of competing groups as shaping these incentives and thereby determining policy outcomes. More concentrated groups, whose members receive relatively higher per capita net benefits from favorable policies and suffer from a

\footnotetext{
${ }^{18}$ Bertero and Rondi (2000).

${ }^{19}$ Bortolotti et. al. (2001).

${ }^{20}$ See, for example, Denzau and Munger (1986), Olson (1965) and Wilson (1980).

${ }^{21}$ See, for example, Peltzman (1976) and Stigler (1971).
} 
relatively low incidence of free-riding, wield greater political influence than do members of less concentrated groups. ${ }^{22}$

Antecedents. Empirical support for the interest group politics perspective can be found in studies showing that larger and more profitable firms, which are argued to be more likely to overcome collective action problems, are more likely to lobby. ${ }^{23}$ Studies considering the incidence and success of lobbying behavior lend further support by demonstrating that the number and diversity of supporting coalitions (including their geographic dispersion) have a strong positive influence on the success of a non-market strategy. ${ }^{24}$ Other studies arrive at mixed conclusions, perhaps due in part to their failure to account for the institutional structure in which interest group pressure plays itself out, a critical issue that we address below. ${ }^{25}$

Of particular interest in the current context is Milner and Yoffie's examination of how interest group pressures on policymakers determine national trade policy. In her earlier work, Milner argues that despite the overall diffuseness of the benefits of free trade and the concentrated benefits of protectionism, we nonetheless observe free trade because of concentrated "export dynamic groups," which receive a particular benefit from free trade and therefore work to overcome the collective actions problems that would otherwise hinder the formation and efficacy of a free trade lobby. ${ }^{26}$

In their later work on strategic protectionism, Milner and Yoffie examine the circumstances in which certain industrial lobbies that were traditionally assumed to favor free trade shifted their position due to increasing scale economies, learning effects and foreign government intervention favoring competitors. They identify the conditions under which these lobbies succeeded in transforming government policy from free trade to strategic protectionism. One such condition is the extent of industry "segmentation": the less fractionalized an industry,

\footnotetext{
${ }^{22}$ Work focusing explicitly on non-market strategy develops more elaborate models of constituent competition in the political arena. See, for example, Snyder (1992), Baron (1994), Baron (1999) and Baron (2001).

${ }^{23}$ See, for example, Salamon and Sigfried (1977), Dickie (1984) and Masters and Keim (1986).

${ }^{24}$ See, for example, Esty and Caves (1983), Yoffie (1988) and Rehbein and Lenway (1994).

${ }^{25}$ Another reason may be the confound of reduced free-riding with industry collusion. See the discussion in Damania and Frederikkson (2000).

${ }^{26}$ Milner (1987) and Milner (1988).
} 
the more likely it is to overcome its collective action problem and lobby aggressively for retaliatory strategic trade policy. ${ }^{27}$

The Lobby for Discipline. The industrial consumers of electricity play an analogous role in our analysis to that of the free trade lobby in Milner's earlier work. We argue that, as a group, industrial consumers are better able to overcome the collective action problems that impede political organization of the broader, more loosely-knit group of electricity consumers incurring net costs from such projects, and therefore exert greater pressure on the government to exercise discipline in the deployment of white elephants.

Industrial consumers receive a relatively small share of the benefits of white elephant projects but bear significant costs through taxes and higher prices, as the same populist motives that lead politicians to use SOEs as a vehicle for employment often lead them to create pricing cross-subsidies from industrial to non-industrial consumers. ${ }^{28}$ To be sure, industrial consumers might be willing to tolerate the direct financial burden of such redistributive policies as a feature of doing business in a given country. However, the burden of low supply reliability in stateowned systems suffering from inadequate maintenance and repair-the implicit cost of white elephants-falls disproportionately on industrial consumers, whose operations typically depend heavily on a reliable and affordable electricity supply. These firms stand to suffer major economic losses from operational disruptions in the form of blackouts, brownouts and “dirty power."

Faced with such costs, industrial consumers exploit their political organizational advantages to exert concerted pressure on political actors for greater financial discipline of SOEs. These advantages follow from the relative concentration of industrial consumers as a group (the inverse of what Milner and Yoffie refer to as "segmentation”) and their possible preexisting affiliation with one another through industry associations and trade groups. ${ }^{29}$ Industrial

\footnotetext{
${ }^{27}$ Milner and Yoffie (1989).

${ }^{28}$ Industrial consumers represent a more stable source of demand than do residential consumers and are consequently less costly to serve. Thus, higher industrial rates are prima facie evidence of cross-subsidization, and lower industrial rates may even reflect cross-subsidization if they do not fully reflect cost differentials.

${ }^{29}$ Industrial firms represent the quintessential organized interest group in the economic theory of regulation. In contrast to our analysis, Stigler (1971) and Peltzman (1976; 1989), addressing the US private ownership context, both conceive of producers exclusively as electric utilities, and "consumers" exclusively as unorganized, residential interests.
} 
consumers may also mobilize residential consumers who either do not live in a region benefiting from a white elephant or do not fully understand the cost that such projects impose on them. ${ }^{30}$ Additionally, large industrial consumers may be able to threaten self-supply, further increasing their bargaining leverage and political influence. We therefore expect political actors to promote white elephants to a lesser degree as industrial representation rises, ceteris paribus.

Hypothesis 1. The rate of white elephant deployment $\left(K_{W E}\right)$ declines as the level of industrial representation $(I R)$ in the consumer base rises, ceteris paribus. That is, $\frac{\partial K_{W E}}{\partial I R}<0$

Figure 1 depicts hypothesis 1 graphically. The horizontal axis measures industrial representation in the consumer base as the fraction of electricity consumed by industrial users (IR), and the vertical axis depicts the rate of white elephant deployment $\left(K_{W E}\right)$ (i.e, the quantity of white elephant capacity deployed during the relevant time period, such as an annual budget cycle). The relationship between "industrial representation" and the rate of white elephant deployment is negative, ceteris paribus, as reflected by the downward slope of the schedule.

The Lobby for White Elephants. The “dual” of Hypothesis 1 would posit a positive relationship between the political strength of the white elephant lobby and the rate of white elephant deployment. We propose no such hypothesis formally because various candidate measures of the former-such as the strength of labor unions and the construction industry-are not widely available enough for use in our empirical application below. It is important to recognize, however, that the lack of an explicit measure of the strength of the pro-white elephant lobby does not alter Hypothesis 1. Hypothesis 1 concerns the marginal effect of the strength of the pro-discipline lobby on the rate of white elephant deployment (i.e., the effect of an increase in $I R$ on $K_{W E}$ while all other influences are held constant), and not the "net" effect of the

\footnotetext{
${ }^{30}$ Organized interest groups seeking self-serving policy changes often attempt to mobilize unaffected groups using a "collective action frame" (Benford and Snow, 2000) that facilitates negative interpretation of the status quo ante by appealing to pre-existing "cultural preoccupations and political biases" (Hilgartner and Bosk, 1988: 63; McFarland, 1991). Research in social movement theory has examined the use of such frames in varied contexts, for example, national competitiveness frames used by interest groups seeking to influence standards for high definition television (Dowell, Swaminathan and Wade, 2002) and environmental justice frames in recycling policy (Lounsbury, Ventresca and Hirsch, 2003). Zajac (1995), in his discussion of "fairness," develops a related insight in a political-economic context, focusing especially on US utility regulation (Henisz and Zelner, 2004).
} 
offsetting influences of the two competing lobbies. ${ }^{31}$ The slope of the deployment schedule Figure 1 reflects the marginal effect of $I R .^{32}$

Figure 1. Industrial Representation and White Elephant Deployment

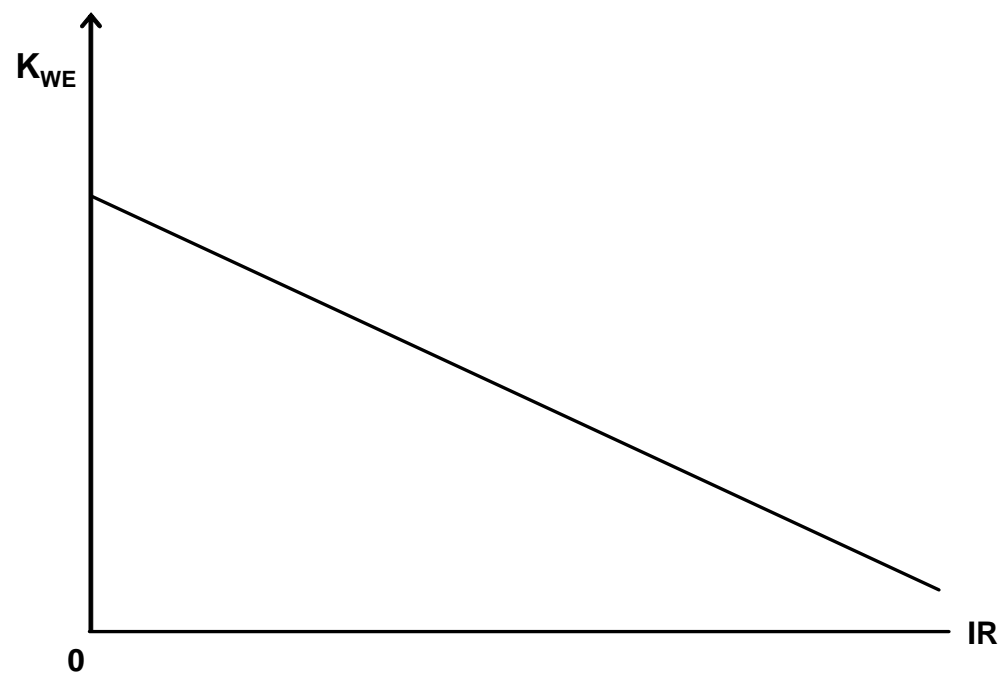

\section{Veto Points}

Interest group politics alone do not determine policy outcomes; rather, the formal institutional structure of the policymaking process may facilitate or impede interest groups'

${ }^{31}$ We nonetheless assume that the rate of white elephant deployment exceeds zero. This assumption is consistent with the conceptual and empirical research on the inefficiency of state-owned enterprises, as well as a substantial amount of anecdotal evidence. It is also consistent with formal theoretical work in political economy (see Boycko, Shleifer and Vishny, 1996; Hart, Shleifer and Vishny, 1997; Laffont and Tirole, 1991; Peltzman, 1989; Shapiro and Willig, 1990; Sheshinski and Lopez-Calva, 1998; Shleifer and Vishny, 1994).

The positive vertical location of the white elephant deployment schedule in Figure 1 reflects this assumption. If, contrary to the assumption, the net effect of interest group pressures were zero deployment of white elephants above some level of $I R$, the schedule would slope downward to the left of that value of $I R$, reach the horizontal axis at that value of $I R$ and correspond to the horizontal axis to the right of it.

${ }^{32}$ In mathematical terms, Hypothesis 1 concerns the partial derivate of the rate of white elephant deployment with respect to the political strength of the pro-discipline lobby. 
attainment of their preferred policy. This structure may influence the amount of pressure that different interest groups can exert on specific policymakers as well as the incentives and ability of these policymakers to respond to such pressure.

Antecedents. Our treatment of formal policymaking institutions is similar in spirit to that of Milner, who in a series of case studies examines how the pressure exerted by export groups favoring free trade combines with the voice and agenda-setting powers granted by formal policymaking institutions to influence trade policy. ${ }^{33}$ Our analysis differs, however, in its quantitative empirical orientation and emphasis on macro-level formal institutions. Specifically, we consider the influence of the level of veto points within a country's legislative branch and among its legislative, executive and judicial branches on policy outcomes. Veto points have the first-order effect of moderating the response of political actors to interest group pressures. Moreover, the level of veto points can be meaningfully compared among the countries in our large- $n$ empirical analysis, in contrast to the more qualitative, micro-level institutional attributes that Milner examines. ${ }^{34}$

Scholars working in the field of positive political theory, especially in the area of "structure-induced equilibrium," emphasize the importance of the veto points in formal policymaking structures. These scholars model how institutional veto points in the U.S. combine with politicians’ electoral preferences to affect policy outcomes. ${ }^{35}$ Under this view, an individual

${ }^{33}$ Milner (1987).

${ }^{34}$ A country's electoral system-e.g., proportional or plurality-based representation-is another broad institution that may influence the degree of political actors' sensitivity to pressure from specific types of interest groups. The literatures on electoral rules and institutional influences on political corruption suggest that electoral institutions may affect the partisan structure and nature of competition among political actors, and therefore the extent to which such actors promote personalistic policies, as opposed to more nationalistic or party-centered ones (Carey and Shugart, 1995; Gaviria, et al., 1999; Myerson, 1993; Panizza, 2001; Rogowski and Kayser, 2002; Shugart, 1999; Wallack, 2003). Electoral rules may also affect the type of benefits that political actors deliver through such rules' effect on party discipline (Ames, 1995; Bowler, Farrell and Katz, 1999; Carey and Shugart, 1995; Reed, 1994).

Although these literatures warrant discussion in the current conceptual context, they ultimately imply an indeterminate relationship between electoral institutions and white elephant deployment. As Kunicova and RoseAckerman (2003) emphasize, systems that promote broad-based, politically-motivated public spending (both legal and illegal) tend not to promote geographically-targeted, politically-motivated public spending, and vice-versa. Yet, as we discuss, political actors deploy white elephants both to benefit constituents in specific regions (through employment, for example) and also to benefit nationalistic interests (for example, the national construction lobby and labor unions). Thus, while electoral institutions may affect the deployment of white elephants, the direction of this relationship is unclear, and it is possible that no relationship will be observed empirically because the contravening effects of system type on geographically-targeted and nationalistic spending may offset each other. As discussed in Footnotes 55 and 60, we nonetheless test for the influence of electoral system type.

${ }^{35}$ See, for example, McNollGast (1987; 1989) and Weingast (1983). 
or institutional actor's possession of veto power over a final policy outcome is among the most important elements of institutional structure. Specifically, any single actor with authority to set policy behaves knowing that the final policy outcome must lie within a range of policies acceptable to all actors with veto power. To the extent that the preferences of the actors with veto power differ, institutional structures with more veto points limit the range of feasible policy choices. As a result, "the potential for policy change decreases with the number of veto players, the lack of congruence (dissimilarity of policy positions among veto players) and the cohesion (similarity of policy positions among the constituent units of each veto player) of these players." 36

Several cross-national empirical studies linking national policy stability to a country's number of veto points support these theoretical insights. Hallerberg and Basinger, for example, find that in response to the stimulus of the Reagan tax cuts enacted by the United States in the 1980s, OECD countries with fewer de facto veto points lowered their tax rates by a greater amount than did countries with more veto points. ${ }^{37}$ Taking a more long-term view, Franzese and Treismann respectively find that countries with more veto points have more stable levels (either high or low) of government deficits and inflation. ${ }^{38}$ MacIntyre proposes a nonlinear relationship between veto points and policy responses to the 1997 East Asian financial crisis and reports supporting qualitative evidence. ${ }^{39}$ Tsebelis demonstrates that veto points limit the output of national legislatures, reduce the volatility of budget expenditures across line items, and are associated with greater independence of the judiciary and central bank. ${ }^{40}$

Current analysis. We concur that policymaking structures with more veto points reduce the degree to which political actors are sensitive to interest group pressures relative to structures with fewer veto points. Figure 2 extends Figure 1 by depicting the white elephant deployment schedule under high and low levels of veto points (with all else still held constant, including pressure from the white elephant lobby). Because an increase in pressure from the lobby favoring SOE discipline, as measured by $I R$, should have a smaller effect on political actors-and

\footnotetext{
36 Tsebelis (1995).

${ }^{37}$ Hallerberg and Basinger (1998).

${ }^{38}$ Franzese (1999b) and Treismann (2000).

${ }^{39}$ MacIntyre (2001).

${ }^{40}$ Tsebelis (2003).
} 
therefore a smaller negative effect on the rate of white elephant deployment-when the level of veto points is higher, we expect the slope of the white elephant deployment schedule to decline as this level increases. That is, an increase in veto points $(V P)$ reduces the magnitude of the negative effect that an increase in the strength of the pro-discipline lobby (measured by $I R$ ) has on the rate of white elephant deployment, ceteris paribus. However, in accordance with Hypothesis 1, in no case should the slope of the schedule become nonnegative.

Hypothesis 2. As the level of institutional veto points in the policymaking process (VP) increases, the absolute magnitude of the negative relationship between industrial representation $(I R)$ and the rate of white elephant deployment $\left(K_{W E}\right)$ declines, ceteris paribus. That is, $\frac{\partial}{\partial V P}\left(\left|\frac{\partial K_{W E}}{\partial I R}\right|\right)<0$.

We do not propose a parallel hypothesis about the marginal effect of veto points on the sensitivity of political actors to the white elephant lobby (and thus the rate of infrastructure deployment) because we cannot directly test such a hypothesis as a result of the data limitations noted above. However, the relationship between the vertical intercepts of the white elephant deployment schedules is consistent with the proposition that the level of veto points conditions the influence of both lobbies on the rate of white elephant deployment in a symmetric manner. In Figure 2, pressure from the pro-white elephant lobby is held constant. The height of the vertical 
Figure 2. Industrial Representation, Veto Points and White Elephant Deployment

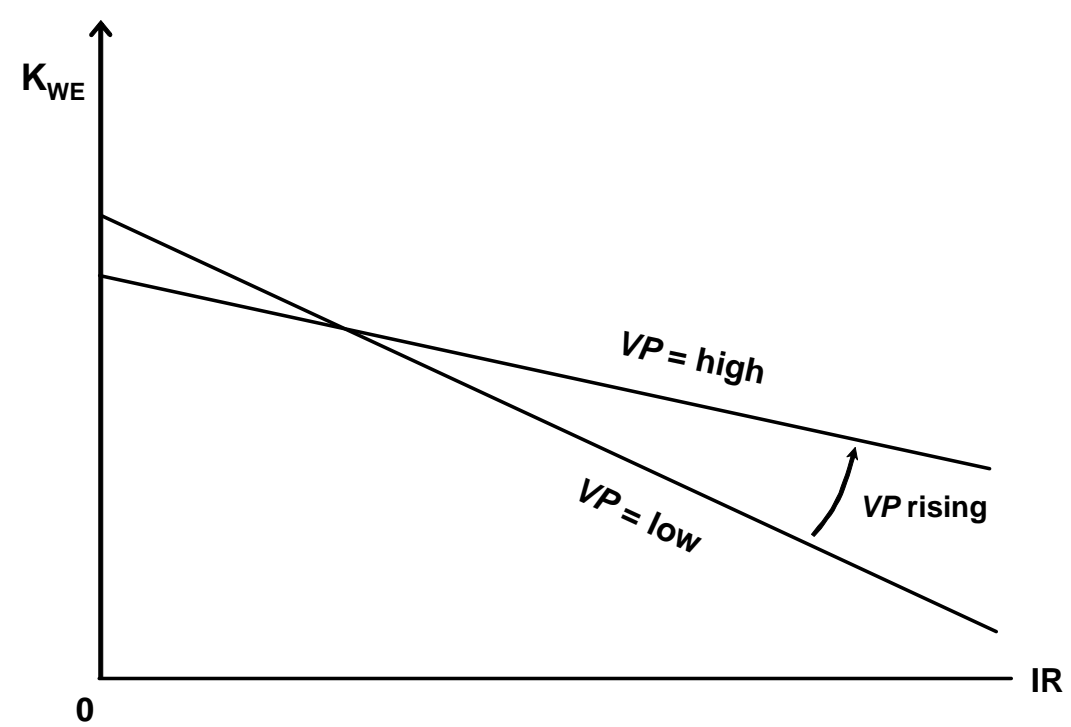

intercept of each white elephant schedule reflects the rate of deployment that the pro-white elephant lobby attains in the absence of a countervailing pro-discipline lobby, ceteris paribus. The vertical intercept of the white elephant deployment schedule reflecting a lower level of veto points (the one with the steeper negative slope) is greater than that of the deployment schedule reflecting a higher level of veto points (the one with the shallower negative slope). To wit, just as an increase in the level of veto points $(V P)$ more greatly reduces the magnitude of the negative effect that an increase in the strength of the pro-discipline lobby (measured by $I R$ ) has on the rate of white elephant deployment, it also more greatly reduces the magnitude of the positive effect that an increase in the strength of the (unobserved) white elephant lobby has on the rate of white elephant deployment, ceteris paribus. ${ }^{41}$

${ }^{41}$ Hypothesis 3 involves the special case often implicitly examined in the literature on the inefficiency of state-owned enterprises, in which political actors are predisposed to serve the pro-white elephant lobby. 
Hypothesis 3. When $I R=0$, an increase in the level of veto points reduces the rate of white elephant deployment $\left(K_{W E}\right)$, ceteris paribus. That is, $\frac{\delta K_{W E}}{\delta V P}<0 \mid I R=0$.

\section{Empirical Test}

We test the hypotheses developed above on a panel dataset covering up to 78 countries during the period 1970 - 1994. The unit of analysis is a country-year. The econometric specification to which the data are applied is derived from the following basic model of investment.

$$
\triangle \text { CAPACITYPC }=f\left(\begin{array}{l}
\text { INDUSTRIAL REPRESENTATION } \\
\text { VETO POINTS } \\
\text { EXISTING CAPACITY LEVEL } \\
\text { DEMAND } \\
\text { FINANCIAL CONSTRAINTS } \\
\text { AVAILABILITY OF FOREIGN SUPPLY } \\
\text { COMPOSITION OF DOMESTIC SUPPLY } \\
\text { COUNTRY DUMMIES } \\
\text { YEAR DUMMIES }
\end{array}\right)
$$

Table 1 provides descriptive statistics for these variables, which we describe at greater length below. 


\section{Table I. Summary Statistics For Variables In Econometric Analysis}

\begin{tabular}{|c|c|c|c|c|c|c|}
\hline$\underline{\text { Variable }}$ & $\underline{N}$ & Mean & $\underline{\text { Median }}$ & Maximum & $\underline{\text { Minimum }}$ & Std. Dev. \\
\hline$\triangle C A P A C I T Y P C$ & 1539 & 0.04 & 0.02 & 2.06 & -0.37 & 0.12 \\
\hline In CAPACITYPC & 1539 & -15.03 & -14.98 & -11.98 & -18.72 & 1.53 \\
\hline IR & 1539 & 0.49 & 0.50 & 0.92 & 0.06 & 0.16 \\
\hline POLCON & 1539 & 0.39 & 0.39 & 0.89 & 0.00 & 0.35 \\
\hline In CHECKS3 & 1341 & 1.27 & 1.39 & 2.83 & 0.00 & 0.51 \\
\hline In EXECCON & 1507 & 1.62 & 1.95 & 2.08 & 0.69 & 0.54 \\
\hline POLITY & 1502 & 2.66 & 7.00 & 10.0 & -10.0 & 7.81 \\
\hline In DEMANDPC & 1539 & -7.02 & -6.92 & -3.76 & -12.42 & 1.69 \\
\hline In IMPORTRAT & 1539 & 3.37 & 1.10 & 10.86 & 0.00 & 3.73 \\
\hline CAPCOST & 1539 & 0.04 & 0.03 & 0.25 & 0.00 & 0.03 \\
\hline COMP_COAL & 1539 & 0.14 & 0.00 & 1.00 & 0.00 & 0.24 \\
\hline COMP_GAS & 1539 & 0.12 & 0.01 & 1.00 & 0.00 & 0.22 \\
\hline COMP_HYDRO & 1539 & 0.41 & 0.34 & 1.00 & 0.00 & 0.34 \\
\hline COMP_NUCLEAR & 1539 & 0.04 & 0.00 & 0.78 & 0.00 & 0.12 \\
\hline COMP_OIL & 1539 & 0.28 & 0.17 & 1.00 & 0.00 & 0.29 \\
\hline
\end{tabular}

\section{A. Dependent Variable}

The dependent variable in the conceptual hypotheses that we advance above is a country's rate of white elephant deployment. Empirically, it is not possible in a wide panel of countries to separate the deployment of white elephant capacity from that of economically “justifiable” deployment without subjectively assessing extremely detailed (and unavailable) data on investment costs and reserve ratios. However, we do not require such a measure to test our hypotheses. Rather, the marginal nature of these hypotheses, noted in their development above, permits us to use objective data on the annual growth rate of total SOE generating capacity (averaging 4.4 percent in the sample) for testing purposes. ${ }^{42}$ Our empirical model allows us to assess how political variables corresponding to those in our hypotheses increase or decrease the annual rate of infrastructure deployment when the economic determinants in our model are

\footnotetext{
${ }^{42}$ It is important to understand that our model does not imply an assumption about the fraction of SOE generating capacity deployment comprised by white elephant deployment.
} 
taken into account-i.e., at the margin. The operative question is, when economic determinants are taken into account, do the political variables have explanatory power, and if so, what are the direction and magnitude of their influence? Statistical insignificance of the political variables would refute our hypotheses, as would coefficients whose sign or relative magnitude were inconsistent with the hypotheses.

\section{B. Independent Variables}

Industrial representation. We measure industrial representation as the one-year lagged ratio of industrial to total electricity consumption (IR). Data used to construct this measure are reported by the International Energy Agency. ${ }^{43}$

Veto points. We measure the level of veto points affecting political actors $(V P)$ in terms of the structure of a country's formal political institutions and the extent of partisan heterogeneity within and among these institutions. We employ two veto point measures developed by Henisz and Beck et al., respectively. ${ }^{44}$

The first step in the construction of Henisz's Political Constraints Index $(P O L C O N)^{45}$ is the identification of the number of independent branches of government (executive, lower and upper legislative chambers, judiciary and sub-federal institutions) with veto power over policy change in each country. Countries lacking any formal veto points are assigned a score of “0.” For all other countries, the majority preference of each of these branches and the status quo policy are then assumed to be independently and identically drawn from a uniform, one-dimensional policy space [0,1]. This assumption allows for the derivation of a quantitative measure of institutional constraints using a simple spatial model of political interaction.

This initial measure is then modified to take into account the extent of alignment across branches of government using data on the party composition of the executive and legislative branches. Alignment across branches increases the feasibility of policy change, thereby reducing the level of political constraints. The measure is then further modified to capture the extent of

\footnotetext{
43 International Energy Agency (1999).

${ }^{44}$ Henisz (2000) and Beck et al. (2001).

${ }^{45}$ Data and codebook are available from http://www-management.wharton.upenn.edu/henisz/POLCON/ ContactInfo.html
} 
preference heterogeneity within each legislative branch. Greater within-branch heterogeneity increases (decreases) the costs of overturning policy for aligned (opposed) branches. Possible scores for the final measure of political constraints range from zero (least constrained) to one (most constrained).

Countries with the greatest level of veto points in the formal policymaking apparatus are those federal states with strong independent judiciaries and either presidential systems or proportional representation electoral rules that tend to yield coalition governments, such as the United States, Germany and Switzerland. Political constraints decrease as the number of veto players declines or as their preferences become more homogeneous, as is the case in moving to a mixed Parliamentary-Presidential system, typified by France or Brazil; to heavily fractionalized Parliamentary systems like those of Belgium, Israel and the Netherlands; to Westminster Parliamentary systems with winner-take-all districts, such as the United Kingdom's. Nondemocratic countries and those with transitional political regimes have the lowest levels of political constraints because the formal institutional structures in these states provide tremendous discretion to policymakers.

The measure developed by Beck et. al., known as CHECKS3, "counts the number of veto players in a political system, adjusting for whether these veto players are independent of each other, as determined by the level of electoral competitiveness in a system, their respective party affiliations, and the electoral rules. ${ }^{, 46}$ The index yields a minimum score of 0 in the absence of an effective legislature. The score then increases linearly with the addition of subsequent veto points whose political preferences are closer to those of the opposition than they are to the average government preference based on a three-point scale calculated using a different methodology for Presidential and Parliamentary systems.

For the former, the opposition is defined as the largest opposition party. The index's value increases by one for each legislative chamber and for the president unless elections are held under closed lists and the president's party is the largest government party in a particular chamber, in which case the president is not considered a check. For the latter, the opposition is defined as the three largest opposition parties. The index's value increases by one for the prime

${ }^{46}$ Beck et. al. (2001). 
minister and for each party in the government coalition including that of the prime minister unless elections are held under closed lists.

In our sample, CHECKS3 and POLCON are correlated at 0.65 . The greatest divergence between the two measures is in their treatment of broad coalition governments. CHECKS3 treats each party as a veto player and thus indicates that countries such as India, Pakistan, Turkey and France have the highest level of veto points, while POLCON indicates that countries such as Germany, Switzerland, Belgium and the United States have the highest level of veto points.

We estimate separate versions of our core regression using the one-year lagged values of POLCON and CHECKS3 as well as two additional measures of interest. The first is EXECCON, which is a subjective scoring of "the extent of institutionalized constraints on the decisionmaking powers of chief executives, whether individuals or collectivities... imposed by any 'accountability groups.',47 Subjective scores such as EXECCON reflect perceptions of underlying institutional structures but lack a clear connection to the underlying characteristics of these structures. They are also more prone to coder bias than are more direct institutional measures. The correlation between EXECCON and POLCON is 0.63 and that between CHECKS3 and EXECCON is 0.74.

In addition to these explicit veto points measures, we also employ the measure POLITY, a widely-used index of democracy also based on subjective coding. Even though this measure bears no explicit relation to institutional constraints, related studies have employed it in under the assumption that democracies exhibit more veto points than do autocracies. ${ }^{48}$ The correlation of POLITY with POLCON is 0.69; with CHECKS3, 0.79; and with EXECCON, 0.95.

Consistent with prior literature, in our specifications using CHECKS3 and EXECCON, we take the natural logarithm of the variable because the distribution of raw levels is skewed to the left.

Existing capacity level. The one-year lagged value of the existing level of capacity per capita (CAPACITYPC) reflects the effect of two influences on the rate of deployment. First, CAPACITYPC measures the economic demand for replacement stock, and should therefore be

\footnotetext{
${ }^{47}$ Gurr (1990).

${ }^{48}$ See, for example, Barro (1996), Leblang (1997) and Rodrik (2000).
} 
negatively correlated with the rate of new infrastructure deployment. ${ }^{49}$ Second, where existing capacity is low, political actors seeking to build white elephants are more easily able to assemble broader political support for the deployment of new infrastructure. Under a higher level of existing capacity, on the other hand, these political actors find it more difficult to assemble broad support because they can no longer as easily make the case for new capacity by appealing to the "common interest" of their colleagues. ${ }^{50}$

As a result, we expect the negative influence of CAPACITYPC to be conditional on that of the political variables of central interest. As $I R$ rises, the incentives that political actors face to exert discipline strengthen, implying that political actors will use a given increase in CAPACITYPC to argue for a greater amount of discipline, leading to a lower rate of deployment of new capacity. That is, the negative marginal effect of CAPACITYPC on the deployment rate should decline as $I R$ rises.

Similarly, the magnitude of the negative marginal effect of CAPACITYPC on the rate of deployment should also depend on the level of veto points that political actors face. A political actor's arguments for discipline in the case of a given increase in CAPACITYPC are less likely to result in approval as the number and breadth of interests of the veto players among which agreement must occur grows. Thus, the magnitude of the negative effect of CAPACITYPC on the deployment rate should decline as VP increases.

In our specification, we use the natural logarithm of CAPACITYPC because the distribution of the variable's raw levels is skewed to the left.

Demand. It is critical to control for the economic demand for new infrastructure. This demand derives from the expected future demand for electricity. However, actual forecasts of expected demand are unavailable for most countries and time periods, and in any case pose the issue of endogeneity in a model whose dependent variable is the rate of capacity deployment.

\footnotetext{
${ }^{49}$ Oliner, Rudebusch and Sichel (1995), in a careful study of alternative empirical investment models, use existing capital stock in an analogous manner, as Lyon and Mayo (2000) do in an empirical study of electric generating capacity investment in the U.S.

${ }^{50}$ It is also possible that when existing capacity is low, the new infrastructure deployed is less likely to include white elephants. Because we do not directly observe the fraction of total capacity deployed comprising white elephants, we cannot directly test this explanation of the proposed negative effect of existing capacity. This possibility further suggests the importance of including CAPACITYPC among our independent variables. It does not, however, alter the interpretation of any observed (marginal) effects of the political variables of central interest. Additionally, our results turn put to be inconsistent with this explanation, as we discuss in footnote 62 .
} 
Following accelerator models of investment ${ }^{51}$ and econometric research on U.S. electricity investment, ${ }^{52}$ we use recent consumption, measured as the prior year's end-user electricity consumption measured in kilowatt hours per capita (DEMANDPC), to proxy for the (unobservable) demand for infrastructure. Recent consumption is clearly exogenous to infrastructure deployment choices, and political actors observe this measure when making deployment choices.

Several previous cross-national studies focus exclusively on Gross Domestic Product (GDP) as a proxy for demand (often without considering supply-side factors, political or otherwise) ${ }^{53}$ We therefore also examine a specification using lagged per capita GDP in place of $D E M A N D P C$ for consistency. In both cases, we use the natural logarithm of the variable rather its raw level because the distribution of the latter is skewed to the left.

Financial Constraints. Ideally, our specification would include a direct measure of a country's cost of capital to reflect differences in the monetary price of capacity expansion. Unfortunately, the data required to construct a comparable measure for state-owned enterprises in a panel of countries are not consistently available. We therefore proxy for a country's cost of capital using lagged gross annual government capital spending as a percentage of Gross Domestic Product, measured in real U.S. dollars (CAPCOST). As this variable increases, reflecting a decline in the country's cost of capital, we expect to observe a higher rate of capacity deployment.

Constraints on government spending more broadly may also affect infrastructure deployment. Variables such as the level of the public sector budget deficit, public debt levels and the inflation rate could all increase the cost of infrastructure deployment and thereby reduce the rate of deployment, ceteris paribus. Unfortunately, the limited data available for each of these variables leads to a substantial loss in sample size. We therefore use CAPCOST as the primary measure in our core specification and conduct sensitivity tests by evaluating the impact of alternative measures in subsamples.

\footnotetext{
${ }^{51}$ See Oliner, Rudebusch and Sichel (1995).

52 Lyon and Mayo (2000).

53 See, for example, Bhatia (1987) and Siddayao (1986).
} 
Availability of Foreign Supplies. Some governments can buy electricity from abroad rather than generate it domestically. ${ }^{54}$ Our specification therefore includes the lagged ratio of imported electricity to total electricity consumed (IMPORTRAT). An alternative source of supply should negatively affect the generating capacity deployment level. In our specification, we use the natural logarithm of IMPORTRAT because the distribution of raw levels of the variable is skewed to the left.

Composition of Domestic Supplies. The composition of a country or region's generating capacity by technology type-i.e., nuclear, coal, oil, gas, hydroelectric and others-is influenced by the magnitude and frequency of daily and seasonal fluctuations in demand. In general, larger "baseload" generating units, with low unit costs and high start-up costs, more efficiently serve relatively stable demand; and smaller "peaking" units, which are more expensive to run but can also be taken on- and offline more easily, more efficiently serve uneven demand.

Although differences in capacity composition should not affect total capacity in a steadystate equilibrium, changes in composition may affect the total level of capacity during transition periods. A strong shift in daily or seasonal demand patterns, for example, might render it efficient to increase baseload capacity, while maintaining existing peaking capacity but keeping it idle most of the time. The phasing out of specific fuel subsidies could have a similar effect. In these cases, total capacity would rise during the transition period. A large change in the relative price of fuel used for a specific generating technology might have a similar effect by rendering the construction of new capacity of another type efficient while retaining existing capacity but keeping it idle.

Data to measure such potential influences directly are unavailable. We therefore include as a proxy a vector of independent variables measuring the percentage of the prior year's generating capacity stock for each major generating technology type (coal, gas, hydro, nuclear, oil and the omitted category of "other").

Country and Year Dummies. Despite our attempt to include a comprehensive set of independent variables that systematically influence SOE infrastructure deployment, we do not possess a variable measuring the strength of a country's pro-white elephant lobby. Throughout our conceptual discussion, we hold the strength (resulting from the level of political

\footnotetext{
${ }^{54}$ For a similar argument applied in the U.S. context, see Lyon and Mayo (2000).
} 
organization) of the white elephant lobby constant. As discussed above-especially in the development of Hypothesis 3-the strength of a country's white elephant lobby acts as a "shift parameter" that increases or decreases the height of the vertical intercept in Figure 2., The country and year dummy variables play an analogous role in our empirical model by effectively permitting the vertical intercept to vary by country and by year, thereby controlling for countrylevel, time-invariant and sample-wide, inter-temporal differences in the white elephant lobby's strength.

In addition to reflecting the strength of the white elephant lobby, these dummy variables also reflect the influence of other potential sources of unobserved heterogeneity. In the case of the country dummies, country-level, time-invariant influences may include colonial legacies; socio-cultural divisions; the composition of output by sector as determined by natural resource endowments; and deployment costs, which may differ based on geography, wages, and the real cost of equipment. In the case of the year dummies, sample-wide, inter-temporal influences may include global trends in technological innovation and increased globalization itself. ${ }^{55}$

\section{Specification}

Our econometric specification is

$$
\begin{aligned}
& \triangle \text { CAPACITYPC }_{i t}=\beta_{0}+\beta_{1} \ln \text { CAPACITYPC }_{i, t-1}+\beta_{2} V P_{i, t-1}+\beta_{3} I_{i, t-1}+
\end{aligned}
$$

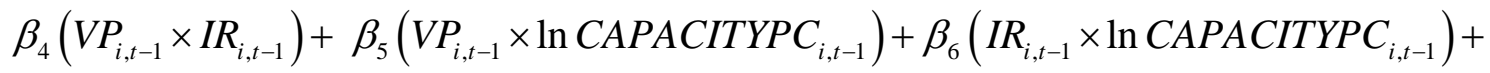

$$
\begin{aligned}
& \left.\beta_{7}\left(V P_{i, t-1} \times I R_{i, t-1} \times \ln \text { CAPACITYPC }_{i, t-1}\right)+\beta_{8} \ln \operatorname{DEMANDPC}_{i, t-1}\right)+\beta_{9} \text { CAPCOST }_{i, t-1}+ \\
& \beta_{10} \ln \text { IMPORTRTAT }_{i, t-1}+\beta_{11} \text { COMP }_{-} C O A L_{i, t-1}+\beta_{12} \text { COMP }_{-} G A S_{i, t-1}+\beta_{13} \text { COMP }_{-} H Y D_{i, t-1}+ \\
& \beta_{14} C O M P \_N U C_{i, t-1}+\beta_{15} C O M P \_O I L_{i, t-1}+\text { COUNTRYDUMS } \lambda_{i}+\text { YEARDUMS } \lambda_{t}+\varepsilon_{i t}
\end{aligned}
$$

\footnotetext{
55 As discussed in footnote 34, a country's electoral system might influence policy choice, but there is no conceptual basis for hypothesizing about the direction of this effect on white elephants and it is possible that no such effect can be observed at all because the effects of electoral system type on the promotion of geographic and nationalistic interests may effectively offset each other. To the extent that a country's electoral system type has a time-invariant observable effect on white elephant deployment, the country dummies should capture this effect as well. We also test our specification on subsamples of the dataset composed of countries with different types of electoral systems and report the results in footnote 60 below.
} 
where the subscripts $i$ and $t$ are cross-sectional (country) and time period indices, the notation $\Delta X_{\mathrm{t}}$ represents the percentage change in the variable $X$ between period $t-1$ and period $t$, and $\ln X$ represents the natural logarithm of $X$. The variable names are those defined in the text above.

The specification includes multiplicative interactions among CAPACITYPC, IR and VP. The inclusion of the interaction terms permits proper statistical evaluation of the conditional effects hypothesized above. ${ }^{56}$ The interaction between $I R$ and VP flows directly from Hypotheses 2 and 3. The interactions between CAPACITYPC and IR, and CAPACITYPC and VP, respectively, allow for the conditional effects suggested in the discussion of CAPACITYPC. ${ }^{57}$ The three-way interaction terms reflect potential higher-order multiplicative effects given the hypothesized two-way effects among IR, VP and CAPACITYPC.

The coefficients are estimated using ordinary least squares. Because the error term is expected to exhibit within-country serial correlation and heteroskedasticity, we employ a robust covariance matrix estimator in order to correct the standard errors. This covariance matrix estimator is consistent in the presence of within-unit serial correlation up to a specified lag and heteroskedasticity of unknown form, and also does not rely on an assumption that the different cross-sectional units share a common autocorrelation parameter. ${ }^{58}$

${ }^{56}$ See Friedrich (1982) and Jaccard, Turisi and Wan (1990).

${ }^{57}$ It is important to recognize that the inclusion of interaction terms does not impose the conditional effects of interest on the empirical model, but rather permit their detection if they exist. Were no conditional effects present, the interaction terms would be statistically insignificant.

${ }^{58}$ The robust covariance matrix estimator is based on that developed by Newey and West (1987) for use in a time-series setting. The conventional Newey-West covariance matrix estimator is:

$$
\hat{\mathbf{V}}=T\left(\mathbf{X}^{\prime} \mathbf{X}\right)^{-1} \mathbf{S}\left(\mathbf{X}^{\prime} \mathbf{X}\right)^{-1}
$$

where

$$
\mathbf{S}=T^{-1}\left(\sum_{t=1}^{T} e_{t}^{2} \mathbf{x}_{t} \mathbf{x}_{t}^{\prime}+\sum_{l=1}^{L}\left(\frac{l}{L+1}\right) \sum_{t=l+1}^{T} e_{t} e_{t-l}\left(\mathbf{x}_{t} \mathbf{x}_{t-l}^{\prime}+\mathbf{x}_{t-l} \mathbf{x}_{t}^{\prime}\right)\right) .
$$

and $\mathbf{X}$ is the regressor matrix, $\mathbf{x}_{\mathbf{t}}$ is a vector representing row $t$ of the regressor matrix, $T$ is the number of time-series observations, $K$ is the number of regressors, $e_{t}$ is a consistent estimator of the disturbances, and $L$ is the lag truncation (i.e., the maximum order of autocorrelation to which the estimator is robust).

The panel version is a straightforward extension of the conventional time-series version. Under the assumption that the $N$ cross-sectional units are independent, $\mathbf{S}_{n}$ is constructed for each unit $n$, and the resulting $N$ values are then averaged to obtain a consistent estimator of S. See Driscoll and Kraay (1998) and Froot (1989). Thanks to Aart Kraay for sharing his insights on this topic. 
We have also taken measures to ensure and demonstrate the robustness of our model. First, we use one-year lagged values of the independent variables in order to mitigate any remaining potential concerns about endogeneity. Second, our specification includes a broad range of possible determinants of the rate of capacity deployment among the independent variables as well as country and year dummies to reduce the possible incidence of systematic unobserved heterogeneity. Finally, we test specifications including several other possible influences on the deployment rate, as described below.

\section{Results}

Table 2 reports the estimation results for the core specification described above and several variants that we use to assess the results' robustness. Column one reports results from the core specification using $P O L C O N$ as the veto point measure $(V P)$. Column two reports results from the core specification using POLCON as the veto point measure (VP) but without the interaction terms, in order to highlight the importance of the interaction between industrial representation and veto points. Columns three through five report results from the core specification using CHECKS3, EXECCON and POLITY, respectively, to measure VP.

Consider the first column. With the exception of certain time period and country dummies (omitted from the table for brevity), the coefficient estimate for each variable or interaction term is individually significant at a p-value of 0.05 or less. However, the individual point estimates of the coefficients for $I R$ and $V P$, the independent variables of primary interest, do not have a meaningful interpretation as a result of the interaction terms in the model. Rather, proper assessment of the effects of $I R$ and $V P$ (as well as CAPACITYPC) on the capacity growth rate ( $\triangle C A P A C I T Y P C)$ depends on the respective estimators

$$
\begin{gathered}
\mathrm{B}_{I R}\left(V P_{t-1}, \text { CAPACITYPC }_{t-1}\right)=\beta_{3}+\beta_{4} V P_{t-1}+\beta_{6} \ln \text { CAPACITYPC }_{t-1}+ \\
\beta_{7} V P_{t-1} \times \ln \text { CAPACITYPC } \\
t-1
\end{gathered}
$$

and its standard error at different levels of $\mathrm{VP}^{59}$; and

\footnotetext{
$t$-statistic:

${ }^{59}$ For purposes of hypothesis testing, it is necessary to compute the standard error of $\mathrm{B}_{I R}$ by employing the
}

$$
t_{I R}=\mathrm{B}_{I R} / \mathrm{SE}\left(\mathrm{B}_{I R}\right)
$$




$$
\begin{aligned}
\mathrm{B}_{V P}\left(I R_{t-1}, \text { CAPACITYPC }_{t-1}\right)= & \beta_{2}+\beta_{4} I R_{t-1}+\beta_{5} \ln \text { CAPACITYPC }_{t-1}+ \\
& \beta_{7} I R_{t-1} \times \ln \text { CAPACITYPC }_{t-1} .
\end{aligned}
$$

and its standard error at different levels of $I R$.

Table 3 reports estimates of $\mathrm{B}_{I R}$ along with p-values when the existing capacity variable $\left(\right.$ CAPACITYPC $\left._{t-1}\right)$ is set to its sample mean value and $V P$ set to different values, as well as estimates of $\mathrm{B}_{V P}$ along with p-values when the existing capacity variable (CAPACITYPC $\left.C_{t-1}\right)$ is set to its sample mean value and $I R$ set to different values. Figure 3 (the empirical analogue of Figure 1) illustrates the results graphically by plotting the predicted effect of industrial representation on the annual deployment rate when VP (measured by POLCON) is respectively set to its sample mean minus one standard deviation (0.04) and mean plus one standard deviation (0.74).

where

$$
\mathrm{SE}\left[\mathrm{B}_{I R}\left(V_{t-1}, \text { CAPACITY }_{t-1}\right)\right]=\left[\begin{array}{l}
\operatorname{var}\left(\beta_{3}\right)+ \\
V P_{t-1}^{2} \operatorname{var}\left(\beta_{4}\right)+ \\
2 V P_{t-1} \operatorname{cov}\left(\beta_{2}, \beta_{4}\right)+ \\
\operatorname{CAPACITY~}_{t-1}^{2} \operatorname{var}\left(\beta_{6}\right)+ \\
2 \text { CAPACITY }_{t-1} \operatorname{cov}\left(\beta_{3}, \beta_{6}\right)+ \\
V P_{t-1}^{2} \operatorname{CAPACITY}_{t-1}^{2} \operatorname{var}\left(\beta_{7}\right)+ \\
2 V P_{t-1} \times \text { CAPACITY }_{t-1} \operatorname{cov}\left(\beta_{3}, \beta_{7}\right)+ \\
2 V P_{t-1} \times \text { CAPACITY }_{t-1} \operatorname{cov}\left(\beta_{4}, \beta_{6}\right)+ \\
2 V P_{t-1}^{2} \operatorname{CAPACITY~}_{t-1} \operatorname{cov}\left(\beta_{4}, \beta_{7}\right)+ \\
2 \operatorname{CAPACITY}_{t-1}^{2} \times V P_{t-1} \operatorname{cov}\left(\beta_{6}, \beta_{7}\right)
\end{array}\right]^{1 / 2}
$$




\section{Table 2. Point Estimates and P-values}

\begin{tabular}{|c|c|c|c|c|c|c|c|c|c|c|}
\hline \multirow[b]{2}{*}{ Variable } & \multicolumn{10}{|c|}{ Specification } \\
\hline & \multicolumn{2}{|c|}{1} & \multicolumn{2}{|c|}{2} & \multicolumn{2}{|c|}{3} & \multicolumn{2}{|c|}{4} & \multicolumn{2}{|c|}{5} \\
\hline C & -1.34 & 0.04 & -2.24 & 0.00 & -1.41 & 0.03 & -1.31 & 0.20 & -1.69 & 0.00 \\
\hline In CAPACITYPC & -0.16 & 0.00 & -0.21 & 0.00 & -0.16 & 0.00 & -0.17 & 0.03 & -0.19 & 0.00 \\
\hline$V P$ & -2.34 & 0.01 & 0.01 & 0.52 & -0.80 & 0.01 & -0.31 & 0.58 & -0.05 & 0.33 \\
\hline IR & -2.74 & 0.01 & -0.19 & 0.04 & -2.29 & 0.02 & -2.66 & 0.13 & -1.32 & 0.07 \\
\hline$V P^{*} I R$ & 4.95 & 0.00 & & & 1.67 & 0.01 & 1.06 & 0.25 & 0.15 & 0.07 \\
\hline In CAPACITYPC*VP & -0.14 & 0.02 & & & -0.05 & 0.02 & -0.02 & 0.66 & -0.00 & 0.39 \\
\hline In CAPACITYPC*IR & -0.15 & 0.02 & & & -0.12 & 0.04 & -0.11 & 0.18 & -0.07 & 0.13 \\
\hline In CAPACITYPC ${ }^{*} V P^{*} I R$ & 0.31 & 0.00 & & & 0.11 & 0.01 & 0.06 & 0.31 & 0.01 & 0.08 \\
\hline In DEMANDPC & 0.14 & 0.00 & 0.14 & 0.00 & 0.13 & 0.00 & 0.15 & 0.00 & 0.15 & 0.00 \\
\hline In IMPORTRAT & -0.24 & 0.00 & -0.25 & 0.00 & -0.28 & 0.02 & -0.26 & 0.00 & -0.25 & 0.00 \\
\hline CAPCOST & 0.36 & 0.05 & 0.31 & 0.09 & 0.23 & 0.20 & 0.31 & 0.08 & 0.35 & 0.05 \\
\hline COMP_COAL & 0.28 & 0.02 & 0.28 & 0.02 & 0.33 & 0.01 & 0.23 & 0.10 & 0.21 & 0.15 \\
\hline COMP_GAS & 0.38 & 0.00 & 0.36 & 0.01 & 0.42 & 0.00 & 0.32 & 0.02 & 0.33 & 0.03 \\
\hline COMP_HYDRO & 0.32 & 0.02 & 0.32 & 0.03 & 0.37 & 0.02 & 0.27 & 0.08 & 0.27 & 0.11 \\
\hline COMP_NUCLEAR & 0.29 & 0.02 & 0.24 & 0.05 & 0.28 & 0.02 & 0.17 & 0.22 & 0.17 & 0.26 \\
\hline COMP_OIL & 0.28 & 0.02 & 0.28 & 0.02 & 0.33 & 0.01 & 0.24 & 0.08 & 0.23 & 0.11 \\
\hline $\mathrm{N}$ & 153 & & 153 & 39 & 134 & 41 & 15 & 07 & & 02 \\
\hline Adjusted R-squared & 0.2 & & 0.21 & 13 & 0.2 & 217 & 0.2 & 20 & 0.2 & 225 \\
\hline Log Likelihood & $14 \varsigma$ & & 148 & 85 & 134 & 44 & 14 & 58 & & 69 \\
\hline
\end{tabular}

Notes: Estimated using one-year lagged values of independent variables.

Coefficients for country and time dummies not reported.

P-values (displayed to the right of the coefficient estimates in italics) based on panel implementation of Newey-West covariance matrix estimator. 
Table 3. $\mathbf{B}_{I R}$ and $\mathbf{B}_{V P}$

\begin{tabular}{|c|c|c|c|c|c|c|}
\hline \multirow[b]{3}{*}{ VP at: } & \multicolumn{6}{|c|}{ Specification } \\
\hline & 1 & 2 & 3 & 4 & 5 & 5 \\
\hline & \multicolumn{6}{|c|}{$\mathrm{B}_{I R}$} \\
\hline Minimum & -0.48 & $0.00-0.19$ & $0.04-0.44$ & $0.00-0.41$ & $0.01-0.44$ & 0.00 \\
\hline Mean - 1SD & -0.45 & $0.00-0.19$ & $0.04-0.39$ & $0.00-0.35$ & $0.01-0.39$ & 0.00 \\
\hline Mean & -0.31 & $0.00-0.19$ & $0.04-0.36$ & $0.00-0.27$ & $0.01-0.36$ & 0.00 \\
\hline Mean + 1SD & -0.16 & $0.04-0.19$ & $0.04-0.33$ & $0.00 *$ & * -0.33 & 0.00 \\
\hline $\begin{array}{l}\text { Maximum } \\
I R \text { at }\end{array}$ & \multicolumn{6}{|c|}{$\mathrm{B}_{V P}$} \\
\hline Minimum & -0.17 & $0.06 \quad 0.01$ & $0.52-0.03$ & $0.18-0.06$ & $0.20-0.03$ & 0.18 \\
\hline Mean - 1SD & -0.06 & $0.23 \quad 0.01$ & $0.52-0.02$ & $0.15-0.02$ & $0.44-0.02$ & 0.15 \\
\hline Mean & 0.01 & 0.840 .01 & $0.52-0.01$ & 0.240 .00 & $0.85-0.01$ & 0.24 \\
\hline Mean + 1SD & 0.07 & $0.04 \quad 0.01$ & 0.520 .00 & $0.94 \quad 0.03$ & 0.040 .00 & 0.94 \\
\hline Maximum & 0.19 & 0.010 .01 & $0.52 \quad 0.02$ & 0.420 .07 & 0.020 .02 & 0.42 \\
\hline
\end{tabular}

Notes: Estimated using one-year lagged values of independent variables.

All independent variables other than $I R$ and $V P$ held at their sample mean.

P-values (displayed to the right of the coefficient estimates in italics) based on panel implementation of Newey-West covariance matrix estimator.

As described in the text, Columns 1 and 2 use POLCON as a measure of $V P$. Column 3 uses $\ln ($ CHECKS3+1), column 4 uses $\ln ($ EXECCON $)$ and column 5 uses POLITY.

*Mean plus one standard deviation is above the maximum observed value and thus not reported. 


\section{Figure 3. Marginal Effect of IR on Capacity Deployment Rate at High and Low Levels of VP}

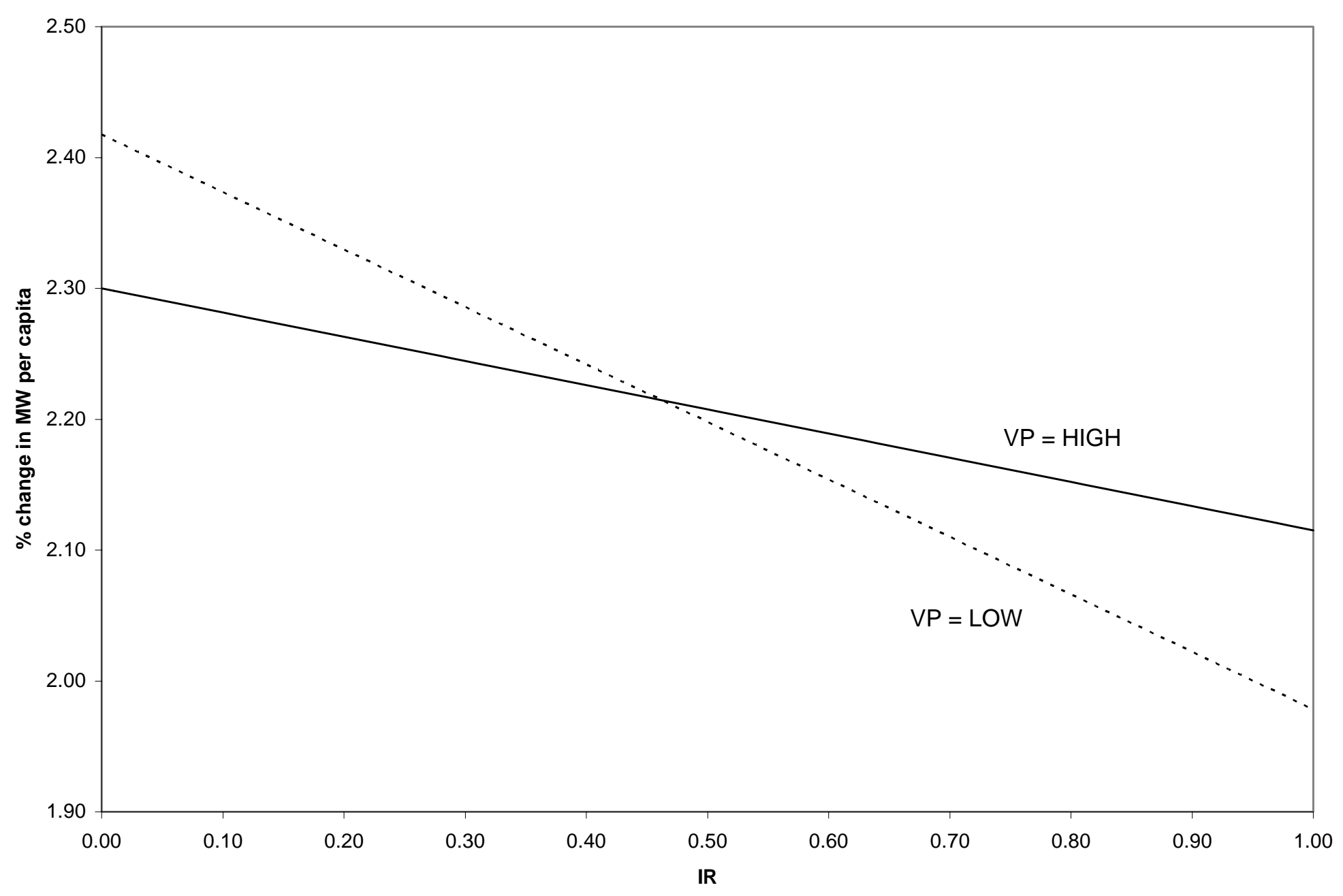

Notes: $\quad$ Figure plotted using coefficient estimates from Specification 1.

Existing capacity level is held at its sample mean.

POLCON is used to measure VP and respectively set to its mean minus one standard deviation (0.04) and mean plus one standard deviation (0.74). 
Effects of IR and VP. Consider the first column of Table 3. Hypothesis 1 states that the marginal effect of $I R$ should be negative (regardless of the level of VP). Consistent with this hypothesis, the effect of $I R$ on the rate of infrastructure deployment when VP (measured here by $P O L C O N$ ) takes any value from its sample minimum to sample maximum is negative, and has a p-value of 0.04 or less at all reported values of $V P$ except for the sample maximum (at which $p=0.21)$.

Hypothesis 2 states that the marginal effect of $I R$ should decline in absolute magnitude as $V P$ increases. When VP is set to its sample mean minus one standard deviation (a low level of veto points), a one standard deviation increase in $I R(0.16)$ yields a predicted decline in the infrastructure deployment rate of 7.2 percentage points (the slope coefficient of -0.45 multiplied by the increase in $I R$ of 0.16 ), equal to 164 percent of the absolute value of the infrastructure deployment rate's sample mean of 4.4 percentage points (or 58 percent of one standard deviation of the infrastructure deployment rate). When $V P$ rises to its sample mean value (0.39), the effect of an increase in $I R$ of one standard deviation (0.16) declines in absolute magnitude to a predicted reduction of 5.0 percentage points (the slope coefficient of -0.31 multiplied by the increase in $I R$ of 0.16 ), equal to 136 percent of the absolute value of the infrastructure deployment rate's sample mean (37.5 percent of one standard deviation). The negative marginal effect of pressure exerted by the lobby favoring discipline therefore declines in absolute magnitude as the level of veto points rises. Moreover, when the level of veto points reaches its sample maximum, this effect declines so much in absolute magnitude that is statistically indistinguishable from zero $(p=0.21)$. These results are consistent with Hypothesis 2 : as the level of veto points imposed by formal institutional structures increases, the negative marginal influence of industrial consumers on infrastructure deployment declines.

Hypothesis 3 addresses the effect of veto points $(V P)$ when $I R=0$. When $I R$ takes its sample minimum value of 0.06 , the marginal effect of $V P$ is negative, with an estimated value of -0.17 and p-value of 0.06 . When $I R$ takes the out-of-sample value of zero, the implied marginal effect of $V P$ is -0.18 , suggesting that a one standard deviation increase in $V P(0.35)$ would generate a predicted decrease in the infrastructure deployment rate of 6.3 percentage points, equal to 155 percent of the absolute value of the deployment rate's sample mean (or 52 percent of one standard deviation). These results are consistent with Hypothesis 3: when political actors are predisposed to cater to the white elephant lobby's demands for increased deployment, the 
marginal effect of veto points $(V P)$ - which reduce political actors' sensitivity to interest group pressures-is a reduction in the deployment rate, ceteris paribus.

Although we have not proposed a formal hypothesis about the effect of veto points (VP) on the rate of deployment at levels of industrial representation (IR) exceeding zero, the pattern of effects of $V P$ at different values of $I R$ is nonetheless informative. First consider the effect of an increase in $V P$ when $I R$ takes its sample mean value. This effect is statistically indistinguishable from zero (the estimate of 0.01 has a p-value 0.84 ). Thus, where there exists some intermediate level of industrial representation (IR) and the level of pressure to build white elephants is held constant, an increase in veto points (VP) has no observable effect on the rate of infrastructure deployment. The lack of an observable effect is consistent with the proposition that such an increase reduces the "sensitivity" of political actors to both the pro-white elephant and prodiscipline lobbies.

When industrial representation $(I R)$ rises to its sample maximum value of 0.92 , the estimated marginal effect of $V P$ is 0.19 with a p-value of 0.01 , implying that a one standard deviation increase in VP would now increase the predicted infrastructure deployment rate by 6.7 percentage points. The marginal effect of veto points $(V P)$ - which reduce political actors' sensitivity to interest group pressures-becomes positive as the strength of the pro-discipline lobby, and thus the predisposition of political actors to cater to this lobby's demands for reduced deployment, grows. ${ }^{60}$

Existing Capacity. The remaining independent variables in the first column of Table 2 are all statistically significant. In order to gauge the effect of the existing capacity level

${ }^{60}$ As discussed in footnote 55, we tested our specification on four subsamples, each comprised of countries with a specific type of electoral system. The estimates of $B_{I R}$ are qualitatively similar to those reported in Table 3 in all of the subsamples and attain statistical significance in many of the same cases. We attribute the loss of statistical significance in the other cases to the substantially smaller size of the subsamples relative to the entire sample (the subsamples range in size from 238 to 540 country-years), and thus the reduced statistical power of our tests.

The estimates of $B_{V P}$ are qualitatively similar to those reported in Table 3 in three of the four subsamples and again attain statistical significance in many of the same cases. The subsample for which the estimates of $B_{V P}$ differ qualitatively from those for the main sample is comprised of countries with "mixed" systems in which different branches of government have fundamentally different types of electoral rules and furthermore consists of only 238 observations, so we have little confidence in the results for this subsample anyway.

No discernible pattern emerges when we compare the estimates of $B_{I R}$ and $B_{V P}$ across the subsamples, nor would we expect one to, as discussed in footnote 55. The qualitative consistency of the estimated coefficients even from these small subsamples does, however, bolster our confidence that the estimates from our full sample do not reflect a spurious relationship involving electoral system type. We rely on the main sample for the analysis contained in the text because of the small size of the subsamples. 
(CAPACITYPC), however, it is necessary to calculate $\mathrm{B}_{C A P A C I T Y P C}$ (analogous to $\mathrm{B}_{I R}$ and $\mathrm{B}_{V P}$ ) because CAPACITYPC is the third variable included in the interaction terms. When VP and IR are permitted to vary within one standard deviation around their sample mean, the total effect of existing capacity level ranges from -0.198 to -0.217 , with a p-value of 0.008 or less. This effect persists in both sign and statistical significance over almost all feasible combinations of values of the three variables, ${ }^{61}$ and thus supports the conjecture advanced above that the deployment rate is inversely related to the existing capacity level. ${ }^{62}$

Demand. The coefficient estimate for DEMANDPC is significant and positively signed, indicating that countries with higher levels of electricity consumption build more capacity. It is informative to compare the magnitude of the estimated coefficients of these economic control variables to those of the political variables of theoretical interest. DEMANDPC is a central economic driver of infrastructure deployment; indeed, as noted above, several previous crossnational studies employ a single measure of demand as their sole independent variable.

In our specification, an increase in DEMANDPC of one standard deviation (1.69), increases the predicted rate of capacity deployment by 24 percentage points, or two standard deviations of the dependent variable. However, when industrial representation (IR) rises to one

${ }^{61}$ Full results for this variable are available from the authors on request.

${ }^{62}$ Our results are consistent with the proposed "political" explanation of the effect of existing capacity level — that it facilitates political arguments for white elephants—and inconsistent with the proposition that a larger fraction of capacity deployed is composed of public goods when $I R$ is low, as discussed in footnote 50 . As we discuss in the text, a common symptom of electricity systems exploited largely for purposes of political patronage is a consistent lack of adequate maintenance and repair that leaves much existing capacity idle. Industrial consumers thus attempt to remedy the undersupply of electricity by asking political actors to direct the SOE to allocate more funding to maintenance and repair rather than new construction of any sort. If the political mechanism that we posit is operative - that political actors can better assemble a coalition supporting a white elephant when existing capacity is low then when it is high-we would expect the marginal effect of existing capacity (CAPACITYPC) to decline in absolute magnitude (but remain negative) as $I R$ rises and political actors are less likely to make arguments for white elephants in the first place. In contrast, if a greater fraction of capacity deployed represents a "true" public good when existing capacity is lower, we would expect industrial consumers not to exercise discipline on the deployment rate when CAPACITYPC is low because in that case much (or most) new capacity would actually help to alleviate the system's chronic lack of reliability. The sign of the coefficient on CAPACITYPC would then be positive at lower levels of $I R$ and negative at higher levels. Alternatively, if the public goods mechanism were more weakly operative and the coefficient negative at all levels of $I R$, we would expect its absolute magnitude to grow rather than decline.

As noted in the text, the effect of CAPACITYPC is negative and statistically significant at all observed values of $I R$. Moreover, although we do not report them in detail, estimates of $B_{\text {CAPACITYPC }}$ actually decline in absolute magnitude as $I R$ rises (from -0.217 at the sample minimum value of $I R$ to -0.198 at the sample maximum value of $I R$ ). These results are consistent with the existence of the political mechanism that we posit. 
standard deviation above its mean (the pro-discipline lobby is relatively strong) and the level of veto points $(V P)$ declines to one standard deviation below its mean (political actors are relatively sensitive to interest group pressure), the predicted negative marginal effect of industrial representation on the rate of capacity deployment is -29 percentage points, which more than offsets the positive marginal effect of DEMANDPC to reduce the predicted rate of capacity deployment by five percentage points. In contrast, when $I R$ declines to one standard deviation below its mean (a relatively weak pro-discipline lobby), the negative effect of industrial representation on the rate of capacity deployment $(-0.45 * 0.33=-15$ percentage points $)$ still reduces the predicted rate of infrastructure deployment, although is no longer larger in absolute magnitude than the positive marginal effect of demand, leading to a predicted net increase in the infrastructure deployment rate of 9 percentage points.

Other independent variables. Our measure of financial constraints, the capital budget of the central government (CAPCOST), is statistically significant and correctly signed, suggesting that countries with looser capital constraints build more capacity. In the sensitivity analysis below, we consider alternate measures of financial constraints.

The ratio of imported electricity to total production is statistically significant with a pvalue of 0.00 , suggesting that the availability of foreign supplies does, on average, dampen the demand for new domestic generation capacity.

Alternative specifications and robustness. Tables 2 and 3 include results from several additional specifications. Column 2 of each table contains the results from a specification that does not include interaction terms. The effect of industrial representation is once again negative and statistically significant, in accordance with Hypothesis 1. Moreover, VP's lack of statistical significance in this specification is consistent with Hypothesis 3: if the marginal effect of VP is negative where industrial representation $(I R)$ is low and positive where $I R$ is high, then the "average" marginal effect of VP-which is what Specification 2 reflects—might well be close to zero.

The results in columns 3-5 are based on specifications that respectively use CHECKS3, EXECCON and POLITY as the veto point measure, respectively. The results are qualitatively similar to those in the first column with respect to the Hypotheses 1 and 2, although the effect of $V P$ in Hypothesis 3 is no longer statistically significant except when $I R$ takes a high value and EXECCON is used as a measure of VP. 
Additional robustness tests revolve around including various additional and alternative economic influences in our set of independent variables. ${ }^{63}$ These include value added in manufacturing, industry and services; urban population percentage; population density; the credit/GDP ratio; and public sector deficit. In no case is the additional variable statistically significant, nor do the coefficients of central interest change substantially when one of the alternative variables is introduced into the analysis. Additional sensitivity analysis reveals that the reported results are not sensitive to influential data points, as the results are robust to the exclusion of outliers in the dependent variable and the independent variables of theoretical interest. $^{64}$

We also substitute lagged per capita GDP into our core specification as our measure of demand and obtain similar results. Finally, we estimate the core specification for subsamples of OECD and non-OECD countries, and obtain qualitatively similar results to those reported.

\section{Discussion and Conclusion}

A higher level of industrial representation among the consumers of electricity mutes political actors' incentives to satisfy the demands of concentrated geographic interests, labor unions and construction firms to build white elephants, reducing the rate of infrastructure deployment. Veto points that constrain political actors moderate the effect of interest group pressures in the hypothesized manner.

Following recent work in the area of trade, monetary and fiscal policymaking, our results demonstrate the feasibility and importance of combining conceptual perspectives on interest group politics and veto points. Where veto points are high are prevalent, interest group pressures have a smaller effect on policy outcomes. The same level of interest group pressure may therefore translate into a different level of "success" in different states or jurisdictions, depending on the formal institutional structure. The analysis further demonstrates the feasibility of capturing international variation in sector-level interest group pressure using readily available economic data.

\footnotetext{
${ }^{63}$ Results available from the authors on request.

${ }^{64}$ Observations are excluded based on the distribution of the relevant independent variable in the full sample. Removing outliers for the remaining independent variables does not change the reported results.
} 
The effects that we find are statistically, economically and substantively important. Consider the case of Argentina as an example. As noted on page 8, prior research finds that the unit cost of investment fell from $\$ 7.2$ million / MW to \$1.9 million / MW after the introduction of market-oriented reforms to the electricity sector. This cost reduction translates into an annual average savings of $\$ 2.74$ billion based on the average 517 MW of new capacity that Argentina deployed annually in out dataset.

For purposes of comparison, suppose that Argentina had not undertaken privatization reforms, but that instead its level of industrial representation had increased from its 1994 value of 41 percent to 57 percent (roughly equivalent to the level found in India and Portugal). Given Argentina's current level of veto points $(P O L C O N=0.54)$, this increase in industrial representation would result in an annual reduction of $722 \mathrm{MW}$ in the rate of generating capacity deployment, saving somewhere up to $\$ 5.2$ billion annually (depending on whether the unit cost of infrastructure also declined. These calculations would change, of course, for a country with a different institutional environment. For example, a one standard deviation increase in the level of veto points (as measured by POLCON) in Argentina's policymaking institutions, to approximately the level of Belgium, would significantly reduce the savings associated with the increased level of industrial representation. In contrast, if the level of veto points fell by one standard deviation, to approximately the level of Paraguay, the effect of the increase in industrial representation would rise in magnitude 1,266 MW annually, saving up $\$ 9.1$ billion annually. ${ }^{65}$

Despite the strong empirical support for our hypotheses, we also note several limitations that warrant additional cross-national econometric work in this area. First, we are unable to measure the political organization of the "white elephant" lobby. Empirical contexts in which national policy debates are easily divisible into consumer versus producer interests, or pit one region against another, would aid in the further development of the empirical approach that we follow here. Second, our measure of interest group pressure for discipline on SOE infrastructure deployment does not reflect qualitative factors that may affect preferences about redistributive policies, such as dominant national beliefs about the role of the state, especially in the

\footnotetext{
${ }^{65}$ We do not mean to imply that the additional cost savings generated by a substantial degradation of Argentina's democracy would be welfare-enhancing, only that the substantive economic effect of changing industrial representation in Argentina over time could be comparable to that of the market-oriented reforms that have already occurred, but will depend upon the level of veto players.
} 
infrastructure sector. Finally, our measure of institutional constraints does not take into account the structure of the regulatory apparatus or subnational variation in political and regulatory structures. Despite these limitations, we still derive robust results consistent with our hypotheses. Better measures should only increase the statistical and economic significance of related findings.

Our ongoing research extends the study of interest group politics and veto players into the more recent period of electricity reform. We examine the timing of privatization and deregulation of the electricity sector as well as subsequent performance. The insights that we have developed here continue to shape this research agenda. Indeed, we believe that it is only possible to understand the dynamics of the policymaking process through joint consideration of factors discussed in different literatures that cross the disciplinary boundaries of public economics, interest group theories of politics and positive political economy. Failure to do so threatens omitted variable bias and potentially erroneous conclusions. Incorporating multiple policymaking influences better reflects the complexity that investors and political actors face as they interact on a day-to-day basis. 


\section{References}

Ames, Barry. 1995. Electoral Rules, Constituency Pressures and Pork Barrel: Bases of Voting in the Brazilian Congress. Journal of Politics 57 (2): 325-43.

Artana, Daniel, Fernando Navajas, and Santiago Urbiztondo. 2001. Regulation Policies Towards Utilities and Competitive Industries: The Case of Argentina. Quarterly Review of Economics and Finance 41: 585-607.

Baron, David. 1991. Majoritarian Incentives, Pork Barrel Programs and Procedural Control. American Journal of Political Science 35 (1): 57-90.

Baron, David P. 1994. Electoral Competition with Informed and Uninformed Voters. American Political Science Review 88 (1): 33-45.

Baron, David P. 1999. Integrated Market and Nonmarket Strategies in Client and Interest Group Politics. Business and Politics 1 (1): 7-34.

Baron, David P. 2001. Private Politics, Corporate Socia Responsibility and Integrated Strategy. Journal of Economics and Management Strategy 10 (1): 7-45.

Barro, Robert. 1996. Democracy and Growth. Journal of Economic Growth 1 (1): 1-27.

Beck, Thorsten, George Clarke, Alberto Groff, Philip Keefer, and Patrick Walsh. 2001. New Tools and New Tests in Comparative Political Economy: The Database of Political Institutions. World Bank Economic Review 15 (1): 165-76.

Benford, Robert D., and David A. Snow. 2000. Framing Processes and Social Movements: An Overview and Assessment. Annual Review of Sociology 26: 611-39.

Bertero, Elisabetta, and Laura Rondi. 2000. Financial Pressure and the Behavior of Public Enterprises under Soft and Hard Budget Constraints: Evidence from Italian Panel Data. Journal of Public Economics 75: 73-98.

Bhatia, Ramesh. 1987. Energy Demand Analysis in Developing Countries: A Review. Energy Journal 8 (Special): 1-33.

Bortolotti, Bernardo, Juliet D'Souza, Marcella Fantini, and William L. Megginson. 2001. Sources of Performance Improvements in Privatized Firms: A Clinical Study of the Global Telecommunications Industry. Mimeo.

Bortolotti, Bernardo, Marcella Fantini, and Domenico Siniscalco. 2000. Privatization and Institutions: A Cross-Country Analysis. CESifo Working Paper Series 375.

Bourbakri, Narjess, and Jean-Claude Cosset. 1997. The Financial and Operating Performance of Newly Privatized Firms: Evidence from Developing Countries. Journal of Finance 53: 1081-110.

Bowler, S., D. Farrell, and R. Katz. 1999. Party Discipline and Parlimentary Government. Columbus, OH: Ohio State University Press.

Boycko, Maxim, Andrei Shleifer, and Robert W. Vishny. 1996. A Theory of Privatization. Economic Journal 106 (March): 309-19.

Cadot, Olivier, Lars-Hendrik Roller, and Andeas Stephan. 1999. A Political Economy Model of Infrastructure Allocation: An Empirical Assessment. Social Science Research Center, Berlin Discussion Paper 99 (15).

Carey, John M., and Matthew Soberg Shugart. 1995. Incentives to Cultivate a Personal Vote: A Rank Ordering of Electoral Formulas. Electoral Studies 14 (4): 417-39.

Chamberlin, John R., and John E. Jackson. 1987. Privatization as Institutional Choice. Journal of Policy Analysis and Management 6 (4): 586-604. 
Damania, Richard, and Per G. Frederiksson. 2000. On the Formation of Industry Lobby Groups. Journal of Economic Behavior and Organization 41 (4): 315-35.

Denzau, Arthur T., and Michael C. Munger. 1986. Legislators and Interest Groups: How Unorganized Interests Get Represented. American Political Science Review 80 (1): 89107.

Dewenter, Kathryn L., and Paul H. Malatesta. 1998. State-Owned and Privately-Owned Firms: An Empirical Analysis of Profitability, Leverage and Labor Intensity. Mimeo.

Dickie, R. 1984. Influence of Public Affairs Office on Corporate Planning and of Corporations on Government Policy. Strategic Management Journal 5 (1): 15-34.

Dowell, Glenn, Anand Swaminathan, and Jim Wade. 2002. Pretty Pictures and Ugly Scenes: Political and Technological Maneuvers in High Definition Television. Advances in Strategic Management 19: 97-134.

Driscoll, John C. , and Aart C. Kraay. 1998. Consistent Covariance Matrix Estimation with Spatially-Dependent Panel Data. Review of Economic and Statistics 80 (4): 549-60.

D'Souza, Juliet, and William L. Megginson. 1999a. The Financial and Operating Performance of Privatized Firms During the 1990s. Journal of Finance 54 (4): 1397-438.

D'Souza, Juliet, and William L. Megginson. 1999b. Sources of Performance Improvement in Privatized Firms: A Clinical Study of the Global Telecommunications Industry. Mimeo.

Dyck, Alexander. 2001. Privatization and Corporate Governance: Principles, Evidence and Future Challenges. World Bank Research Observer 16 (Spring): 59-84.

Esty, C., and R.E. Caves. 1983. Market Structure and Political Influence: New Data on Political Expenditures, Activity and Success. Economic Inquiry 21: 24-38.

Franzese Jr., Robert J. 1999a. Partially Independent Central Banks, Politically Responsive Governments and Inflation. American Political Science Review 43 (3): 681-706.

Franzese Jr., Robert J. 1999b. The Positive Political Economy of Public Debt: An Empirical Examination of the Oecd Postwar Debt Experience. Mimeo.

Friedrich, R. J. 1982. In Defense of Multiplicative Terms in Multiple Regression Equations. American Journal of Political Science 26 (4): 797-833.

Froot, Kenneth A. 1989. Consistent Covariance Matrix Estimation with Cross-Sectional Dependence and Heteroskedasticity in Financial Data. Journal of Financial and Quantitative Analysis 24 (3): 333-55.

Garrett, Geoffrey, and Peter Lange. 1995. Internationalization, Institutions and Political Change. International Organization 49 (4): 627-55.

Gaviria, Alejandro, Ugo Panizza, Jessica Seddon, and Ernesto Stein. 1999. Political Institutions and Growth Collapses. Mimeo.

Hallerberg, Mark, and Scott Basinger. 1998. Internationalization and Changes in Tax Policy in Oecd Countries: The Importance of Domestic Veto Players. Comparative Political Studies 31 (3): 321-52.

Hart, Oliver, Andrei Shleifer, and Rovert W. Vishny. 1997. The Proper Scope of Government: Theory and an Application to Prisons. Quarterly Journal of Economics: 1127-61.

Henisz, Witold J., and Bennet A. Zelner. 2004. Legitimacy, Interest Group Pressures and Change in Emergent Institutions: The Case of Foreign Investors and Host Country Governments. Academy of Management Review 29 (Forthcoming).

Henisz, Witold Jerzy. 2000. The Institutional Environment for Economic Growth. Economics and Politics 12 (1): 1-31. 
Hilgartner, Stephen, and Charles L. Bosk. 1988. The Rise and Fall of Social Problems: A Public Arenas Model. American Journal of Sociology 94 (1): 53-78.

Hird, John A. 1991. The Political Economy of Pork: Project Selection at the U.S. Army Corps of Engineers. American Political Science Review 85 (2): 429-56.

Jaccard, James, Robert Turisi, and Choi K. Wan. 1990. Interaction Effects in Multiple Regression. London: Sage.

Karp, Larry, and Jeffrey Perloff. 1995. Why Industrial Policies Fail: Limited Commitment. International Economic Review 36 (4): 887-905.

Kunicova, Jana, and Susan Rose-Ackerman. 2003. Electoral Rules as Constraints on Corruption. Mimeo.

La Porta, Rafael, and Florencio Lopez-de-Silanes. 1999. The Benefits of Privatization: Evidence from Mexico. Quarterly Journal of Economics 114 (4): 1193-242.

Laffont, Jean-Jacques, and Jean Tirole. 1991. Privatization and Incentives. Journal of Law, Economics \& Organization 7 (September): 84-103.

Leblang, David A. 1997. Political Democracy and Economic Growth: Pooled Cross-Sectional and Time-Series Evidence. British Journal of Political Science 27: 453-72.

Levy, Brian, and Pablo T. Spiller. 1994. The Institutional Foundations of Regulatory Commitment: A Comparative Analysis of Telecommunications Regulation. Journal of Law, Economics and Organization 10 (2): 201-46.

Levy, Brian, and Pablo T. Spiller. 1996. Regulations, Institutions and Commitment. Cambridge: Cambridge University Press.

Lohmann, Susanne. 1998. Federalism and Central Bank Independence: The Politics of German Monetary Policy, 1957-1992. World Politics 50 (April): 401-46.

Lohmann, Susanne, and Sharyn O'Halloran. 1994. Divided Government and U.S. Trade Policy: Theory and Evidence. International Organization 48 (4): 595-632.

Lounsbury, Michael, Marc J. Ventresca, and Paul M. Hirsch. 2003. Social Movements, Field Frames and Industry Emergence: A Cultural-Political Perspective on U.S. Recycling. Socio-Economic Review Forthcoming.

Lyon, Thomas P., and John W. Mayo. 2000. Regulatory Opportunism and Investment Behavior. Mimeo.

MacIntyre, Andrew. 2001. Institutions and Investors: The Politics of the Financial Crisis in Southeast Asia. International Organization 55 (1): 81-122.

Magyar Villamos Muvek. 2000. Statistical Data, 1999. 37 (2).

Mansfield, Edward D., and Marc L. Busch. 1995. The Political Economy of Nontariff Barriers: A Cross-National Analysis. International Organization 49 (4): 723-49.

Masters, M.S., and G. Keim. Variation in Corporate Pac and Lobbying Activity: An Organizational and Environmental Analysis. In Research in Corporate Social Performance and Policy, edited by J.E. Post, 249-72 Greenwich, CT: JAI Press.

McCubbins, Matthew D., Roger G. Noll, and Barry R. Weingast. 1987. Administrative Procedures as Instruments of Political Control. Journal of Law, Economics and Organization 3 (2): 243-77.

McCubbins, Matthew D., Roger G. Noll, and Barry R. Weingast. 1989. Structure and Process, Politics and Policy: Administrative Arrangements and the Political Control of Agencies. Virginia Law Review 75: 431-82.

McFarland, Andrew S. 1991. Interest Groups and Political Time: Cycles in America. British Journal of Political Science 21 (3): 257-84. 
Megginson, William L, Robert C Nash, and Matthias Van Randenborgh. 1994. The Financial and Operating Performance of Newly Privatized Firms: An International Empirical Analysis. Journal of Finance 49 (2): 403-52.

Megginson, William L, and Jeffry M. Netter. 2001. From State to Market: A Survey of Empirical Studies on Privatization. Journal of Economic Literature 39: 321-89.

Milner, Helen V. 1987. Resisting the Protectionist Temptation: Industry and the Making of Trade Policy in France and the United States During the 1970s. International Organization 41 (4): 639-65.

Milner, Helen V. 1988. Trading Places: Industries for Free Trade. World Politics 40 (3): 350-76. Milner, Helen V., and David B. Yoffie. 1989. Between Free Trade and Protectionism: Strategic Trade Policy and a Theory of Corporate Trade Demands. International Organization 43 (2): 239-72.

Myerson, R. 1993. Effectiveness of Electoral Systems for Reducing Government Corruption: A Game Theoretic Analysis. Games and Economic Behavior 5: 118-32.

Newbery, David. 1998. The Czech Energy Sector. Mimeo.

Newey, Whitney K., and Kenneth D. West. 1987. A Simple, Positive Semi-Definite, Heteroskedasticity and Autocorrelation Consistent Covariance Matrix. Econometrica 55 (5): 703-08.

Nollen, Stanley D., and Dennis P. Quinn. 1994. Endogenous Protection in the United States, 1900-1984. International Organization 48 (Summer): 491-525.

Oliner, Stephen D., Glenn D. Rudebusch, and Daniel E. Sichel. 1995. New and Old Models of Business Investment: A Comparison of Forecasting Performance. Journal of Money, Credit and Banking 27 (3): 806-26.

Olson, Mancur. 1965. The Logic of Collective Action: Public Goods and the Theory of Groups. Cambridge, MA: Harvard University Press.

Panizza, Ugo. 2001. Electoral Rules, Political Systems and Institutional Quality. Economics and Politics 13 (3): 311-42.

Peltzman, Sam. 1976. Toward a More General Theory of Regulation. Journal of Law and Economics 19: 211-48.

Peltzman, Sam. The Control and Performance of State-Owned Enterprises. In Privatization and State-Owned Enteprises, edited by Paul et. al. MacAvoyBoston, MA: Kluwer Academic Publishers.

Reed, S.R. 1994. Democracy and the Personal Vote: A Cautionary Tale from Japan. Electoral Studies 13 (1): 17-28.

Rehbein, Kathleen, and Stefanie Lenway. 1994. Determining an Industry's Political Effectiveness with the U.S. International Trade Commission. Business \& Society 33 (3): 270-92.

Rodrik, Dani. 1994. What Does the Political Economy Literature on Trade Policy (Not) Tell Us That We Ought to Know. National Bureau for Economic Research Working Paper 4870.

Rodrik, Dani. 2000. Institutions for High-Quality Growth: What They Are and How to Acquire Them. Studies in Comparative International Development 35 (3): 3-31.

Rogowski, Ronald, and Mark Andreas Kayser. 2002. Majoritarian Electoral Systems and Consumer Power: Price-Level Evidence from the Oecd Countries. American Journal of Political Science 46 (3): 526-39. 
Salamon, Lester M., and John J. Sigfried. 1977. Economic Power and Political Influnece: The Impact of Industry Structure on Public Policy. American Political Science Review 71: 1026-43.

Savedoff, William, and Pablo Spiller. Government Opportunism and the Provision of Water. In Government Opportunism and the Provision of Water, edited by William Savedoff and Pablo SpillerWashington D.C.: InterAmerican Development Bank.

Shapiro, Carl, and Robert D. Willig. Economic Rationales for the Scope of Privatization. In The Political Economy of Public Sector Reform and Privatization, edited by Ezra Sulieman and John WaterburySan Francisco: Westview Press.

Shepsle, Kenneth, and Barry R. Weingast. 1981. Political Preferences for the Pork Barrel: A Generalization. American Journal of Political Science 25: 96-111.

Sheshinski, Eytan, and Luis Felipe Lopez-Calva. 1998. Privatization and Its Benefits. Mimeo.

Shleifer, Andrei, and Robert W. Vishny. 1994. Politicians and Firms. Quarterly Journal of Economics 109 (4): 995-1025.

Shugart, Mathew Soberg. 1999. Efficiency and Reform: A New Index of Government Responsiveness and the Conjunction of Electoral and Economic Reform. Mimeo.

Sidak, J. Gregory, and Daniel F. Spulber. 1997. Deregulatory Takings and the Regulatory Contract: The Competitive Transformation of Network Industries in the United States. New York: Cambridge University Press.

Siddayao, Corazon M. 1986. Energy Demand and Economic Growth: Measurement and Conceptual Issues in Policy Analysis. Boulder: Westview Press.

Snyder, James M. Jr. 1992. Committee Power, Structure-Induced Equilibria and Roll Call Votes. American Journal of Political Science 36 (1): 1-30.

Soto, Raimundo. 1999. Institutional Reforms in the Electricity Sector. Universidad Alberto Hurtado Departamento de Economia y Administracion Documentos de Investigacion 120.

Spiller, Pablo T. 1993. Institutions and Regulatory Commitment in Utilities' Privatization. Industrial and Corporate Change 2 (3): 387-450.

Stigler, George J. 1971. The Theory of Economic Regulation. Bell Journal of Economic and Management Science 2: 3-21.

Treisman, Daniel. 2000. Decentralization and Inflation: Commitment, Collective Action or Continuity. American Political Science Review 94 (4): 837-57.

Tsebelis, George. 1995. Decision-Making in Political Systems: Veto Players in Presidentialism, Parliamentarism, Multicameralism and Multipartyism. British Journal of Political Science 25 (3): 289-325.

Tsebelis, George. 2003. Veto Players: How Political Institutions Work. Princeton, NJ: Princeton University Press and Russell Sage Foundation.

Vining, Aidan, R. , and Anthony E. Boardman. 1989. Ownership and Performance in Competitive Environments: A Comparison of the Performance of Private, Mixed and State-Owned Enterprises. Journal of Law \& Economics 32 (April): 1-33.

Wallack, Jessica Seddon. 2003. Political Particularism around the World. World Bank Economic Review Forthcoming.

Weingast, Barry, and Mark Moran. 1983. Bureaucratic Discretion or Congressional Control? Regulatory Policymaking by the Federal Trade Commission. Journal of Political Economy 91 (5): 765-800. 
Williamson, Oliver E. 1976. Franchise Bidding with Respect to Catv and in General. Bell Journal of Economics (Spring): 73-104.

Willig, Robert D. 1994. Public Versus Regulated Private Enterprise. Proceedings of the World Bank Annual Conference on Development Economics 1993: 155-80.

Wilson, James Q. The Politics of Regulation. In The Politics of Regulation, edited by Wilson, 319-36 New York: Basic Books.

World Bank. 1995. Bureaucrats in Business: The Economics and Politics of Government Ownership. New York: Oxford University Press.

Yoffie, David B. 1988. How an Industry Builds Political Advantage. Harvard Business Review (May-June): 82-89.

Zajac, Edward E. 1995. Political Economy of Fairness. Cambridge, MA: MIT Press. 


\section{DAVIDSON INSTITUTE WORKING PAPER SERIES - Most Recent Papers}

The entire Working Paper Series may be downloaded free of charge at: www.wdi.bus.umich.edu

CURRENT AS OF 7/21/04

\begin{tabular}{|c|c|c|}
\hline Publication & Authors & Date \\
\hline $\begin{array}{l}\text { No. 711: Interest Groups, Veto Points and Electricity Infrastructure } \\
\text { Deployment }\end{array}$ & $\begin{array}{l}\text { Witold J. Henisz and Bennet A. } \\
\text { Zelner }\end{array}$ & July 2004 \\
\hline $\begin{array}{l}\text { No. 710: Firms' Price Markups and Returns to Scale in Imperfect } \\
\text { Markets: Bulgaria and Hungary }\end{array}$ & $\begin{array}{l}\text { Rumen Dobrinsky, Gábor Körösi, } \\
\text { Nikolay Markov, and László } \\
\text { Halpern }\end{array}$ & July 2004 \\
\hline $\begin{array}{l}\text { No. 709: The Stability and Growth Pact from the Perspective } \\
\text { of the New Member States }\end{array}$ & Gábor Orbán and György Szapáry & July 2004 \\
\hline $\begin{array}{l}\text { No. 708: Contract Violations, Neighborhood Effects, and Wage Arrears } \\
\text { in Russia }\end{array}$ & $\begin{array}{l}\text { John S. Earle and Klara } \\
\text { Sabirianova Peter }\end{array}$ & July 2004 \\
\hline $\begin{array}{l}\text { No. 707: Determinants of Employment Growth at MNEs: Evidence } \\
\text { from Egypt, India, South Africa and Vietnam }\end{array}$ & $\begin{array}{l}\text { Sumon Kumar Bhaumik, Saul } \\
\text { Estrin and Klaus Meyer }\end{array}$ & July 2004 \\
\hline $\begin{array}{l}\text { No. 706: Economic Reform in Tanzania and Vietnam: A Comparative } \\
\text { Commentary }\end{array}$ & $\begin{array}{l}\text { Brian Van Arkadie and Do Duc } \\
\text { Dinh }\end{array}$ & June 2004 \\
\hline $\begin{array}{l}\text { No. 705: Beliefs about Exchange-Rate Stability: Survey Evidence } \\
\text { from the Currency Board in Bulgaria }\end{array}$ & $\begin{array}{l}\text { Neven T. Valev and John A. } \\
\text { Carlson }\end{array}$ & June 2004 \\
\hline No. 704: Returns to Schooling in China Under Planning and Reform & $\begin{array}{l}\text { Belton M. Fleisher and Xiaojun } \\
\text { Wang }\end{array}$ & June 2004 \\
\hline $\begin{array}{l}\text { No. 703: Return to Skills and the Speed of Reforms: Evidence from } \\
\text { Central and Eastern Europe, China and Russia }\end{array}$ & $\begin{array}{l}\text { Belton M. Fleisher, Klara } \\
\text { Sabirianova Peter, and Xiaojun } \\
\text { Wang }\end{array}$ & June 2004 \\
\hline $\begin{array}{l}\text { No. 702: What Makes Small Firms Grow? Finance, Human Capital, } \\
\text { Technical Assistance, and the Business Environment in Romania }\end{array}$ & $\begin{array}{l}\text { J. David Brown, John S. Earle } \\
\text { and Dana Lup }\end{array}$ & May 2004 \\
\hline $\begin{array}{l}\text { No. 701: The Effects of Multiple Minimum Wages Throughout the } \\
\text { Labor Market }\end{array}$ & $\begin{array}{l}\text { T. H. Gindling and Katherine } \\
\text { Terrell }\end{array}$ & May 2004 \\
\hline No. 700: Minimum Wages, Inequality and Globalization & $\begin{array}{l}\text { T. H. Gindling and Katherine } \\
\text { Terrell }\end{array}$ & May 2004 \\
\hline No. 699: Self-Selection and Earnings During Volatile Transition & Ralitza Dimova and Ira Gang & May 2004 \\
\hline No. 698: Ecology and Violence: The Environmental Dimensions of War & $\begin{array}{l}\text { Timothy L. Fort and Cindy A. } \\
\text { Schipani }\end{array}$ & May 2004 \\
\hline $\begin{array}{l}\text { No. 697: Russian Cities in Transition: The Impact of Market Forces in } \\
\text { the 1990s }\end{array}$ & Ira N. Gang and Robert C. Stuart & May 2004 \\
\hline $\begin{array}{l}\text { No. 696: Firm Ownership and Internal Labor Practices in a Transition } \\
\text { Economy: An Exploration of Worker Skill Acquisition in Vietnam }\end{array}$ & Jed Friedman & May 2004 \\
\hline No. 695: The Unanticipated Effects of Insider Trading Regulation & $\begin{array}{l}\text { Art A. Durnev and Amrita S. } \\
\text { Nain }\end{array}$ & May 2004 \\
\hline $\begin{array}{l}\text { No. 694: Volatile Interest Rates, Volatile Crime Rates: A New } \\
\text { Argument for Interest Rate Smoothing }\end{array}$ & Garett Jones and Ali M. Kutan & May 2004 \\
\hline $\begin{array}{l}\text { No. } 693 \text { Money Market Liquidity under Currency Board - Empirical } \\
\text { Investigations for Bulgaria }\end{array}$ & $\begin{array}{l}\text { Petar Chobanov and Nikolay } \\
\text { Nenovsky }\end{array}$ & May 2004 \\
\hline $\begin{array}{l}\text { No. 692: Credibility and Adjustment: Gold Standards Versus Currency } \\
\text { Boards }\end{array}$ & $\begin{array}{l}\text { Jean Baptiste Desquilbet and } \\
\text { Nikolay Nenovsky }\end{array}$ & May 2004 \\
\hline $\begin{array}{l}\text { No. 691: Impact of Cross-listing on Local Stock Returns: Case of } \\
\text { Russian ADRs }\end{array}$ & Elena Smirnova & May 2004 \\
\hline $\begin{array}{l}\text { No. 690: Executive Compensation, Firm Performance, and State } \\
\text { Ownership in China:Evidence from New Panel Data }\end{array}$ & Takao Kato and Cheryl Long & May 2004 \\
\hline $\begin{array}{l}\text { No. 689: Diverging Paths: Transition in the Presence of the Informal } \\
\text { Sector }\end{array}$ & Maxim Bouev & May 2004 \\
\hline $\begin{array}{l}\text { No. 688: What Causes Bank Asset Substitution in Kazakhstan? } \\
\text { Explaining Dollarization in a Transition Economy }\end{array}$ & Sharon Eicher & May 2004 \\
\hline $\begin{array}{l}\text { No. 687: Financial Sector Returns and Creditor Moral Hazard: Evidence } \\
\text { from Indonesia, Korea and Thailand }\end{array}$ & $\begin{array}{l}\text { Ayse Y. Evrensel and Ali M. } \\
\text { Kutan }\end{array}$ & May 2004 \\
\hline $\begin{array}{l}\text { No. 686: Instability in Exchange Rates of the World Leading } \\
\text { Currencies: Implications of a Spatial Competition Model }\end{array}$ & $\begin{array}{l}\text { Dirk Engelmann, Jan Hanousek } \\
\text { and Evzen Kocenda }\end{array}$ & May 2004 \\
\hline
\end{tabular}

